(RESEARCH ARTICLE)

\title{
Influence of soil physicochemical parameters on species composition and structure in the Togo Plateau Forest Reserve in Ghana
}

\author{
Gilchrist K Faith Dogor 1, ${ }^{*}$, Emmanuel Acquah 2 and Alexander K. Anning 1 \\ ${ }^{1}$ Department of Theoretical and Applied Biology, College of Science, Kwame Nkrumah University of Science and \\ Technology, Kumasi, Ghana. \\ 2 Department of Forest Resources Technology, College of Agriculture and Natural Resources, Kwame Nkrumah University \\ of Science and Technology, Kumasi, Ghana.
}

Publication history: Received on 10 December 2020; revised on 18 December 2020; accepted on 20 December 2020

Article DOI: https://doi.org/10.30574/wjarr.2020.8.3.0480

\begin{abstract}
Soil-Species correlation studies help in understanding the ecology of plateau ecosystems. However, this information is scarse thereby posing a challenge in their effective management in Ghana. Hence, the study on the influence of soil physicochemical parameters on species composition and structure in the six fringed communities which constitute the focus of the study: Bowuri (BO), Nkonya (NK), Akpafu (AK), Santrokofi (SA), Hohoe (HH) and Alavanyo (AL) in the Togo Plateau Forest Reserve in Ghana. Soil and vegetation parameters were recorded in a total of 180 plots (each measuring $25 \mathrm{~m} \times 25 \mathrm{~m}$ ) demarcated across the communities and analyzed. Canonical Correlation Analysis (CCA) results showed that pH, OC, TN, OM, TCa, TMg, TK, Na, T.E.B, ex. Acidity, ECEC, Base sat, AVI - P (ppmP), Sand and Silt were the drivers of trees, saplings and seedlings composition and structure (including density, richness, shannon, evenness and basal area (BA)) on the plateau. This vegetation attributes were seen to be highest and more correlated with soil parameters for BO, NK and AK occupying lowland areas and lowest in the SA, HH and AL occupying highland areas of the plateau. The soil is somewhat weak acidic to neutral, with a pH ranging between 4.17 and 7.06. The $\mathrm{CV}$ values revealed Base sat showing lowest values (c.v.<15\%), with moderate (c.v.=34\%-15\%) for TK and highest (c.v.>35\%) for TCa, TMg, Na, T.E.B, EX. ACIDITY and ECEC, AVI-P1. This study provides a better understanding of the current status of this plateau in Ghana.
\end{abstract}

Keywords: Togo Plateau; Forest reserve; Soil physico-chemical properties; biodiversity hotspots

\section{Introduction}

Soil physico-chemical parameters and vegetation are reportedly linked [7, 14, 5, 8], in the sense that soils play a major role in the heterogeneity of habitats, thus contributing to physiognomic differentiation of vegetation and ultimately changes the composition and structure of species across landscape sites [6,14], and also gives support (moisture, nutrient, and anchorage) for vegetation to thrive. Vegetation however, provides protective cover for soil, suppresses soil erosion, and helps to maintain soil nutrient through litter accumulation and subsequent decay (nutrient cycling) [7, $14,11]$. Soil-Species correlation studies must be the first step in understanding the diversity and ecology of plateau ecosystems [1,5], because knowledge of the diversity and ecological needs of the species will provide a clue in developing the species particularly species growing in special locations across plateau fringed communities [8, 14]. And also aid in the soil-vegetation ecosystem model development $[10,13]$. Several studies have found a deep correlation between soil physico-chemical parameters and vegetation composition and structure in plateau ecosystems and have reported soil nutrient content and soil depth to affect basal area and consequently influence structure of plant

\footnotetext{
${ }^{*}$ Corresponding author: Gilchrist K Faith Dogor

Department of Theoretical and Applied Biology, College of Science, Kwame Nkrumah University of Science and Technology, Kumasi, Ghana.
} 
communities [14], soil fertility which positively correlates with species richness [1], Organic Matter (OM) and Nitrogen $(\mathrm{N})$ availability which often constrains productivity $[7,12]$. For plant growth, soil $\mathrm{N}$ and $\mathrm{P}$ were major nutrient elements, which influence the photosynthesis process and other processes related to plant production $[10,13]$ and $\mathrm{C} / \mathrm{N}$ ratio, and $\mathrm{pH}$ which positively correlates with diversity $[6,8,11]$. Other studies believed that a significantly positive correlation of vegetation exists with OC, TCa, TP, TK, TMg, Na, T.E.B, EX. ACIDITY, ECEC, and AVI-P 1 in tropical forests [3, 2].Soil physico-chemical parameter have a role to play in vegetation composition and structure in plateau ecosystems, and is important to vegetation managers and ecologists for meaningful management strategy $[3,2,7,12]$. Unfortunately, with regard to establishing soil - vegetation relationships, available information is scarce and scanty particularly in Africa [2].

The Togo Plateau Forest Reserve, is the largest forest reserve in the Volta Region of Ghana and is recognized as a biodiversity significant area $[1,8,14]$. The reserve is characterized by horizontal layers of sedimentary rocks, a wide range in elevation, hundreds of escarpment, flat-topped plateaus and rocky mountain provinces. Its high topographic complexity has created different soil compositions as a result, and have developed different life zones that support different vegetation communities.

The reserve is important for the fringe communities as they rely on it heavily for their traditional healthcare needs, and also provides cool climate, unique topography, a potential tourist site and supports high level of endemism [1, 14]. Despite these enormous benefits, the composition and structure of the Plateau has not been studied. Its ecological needs and major threats are thus not understood, and the conservation requirements are not appreciated [9]. This dearth of scientific information is certainly presenting a major limitation for the effective management and conservation of the reserve. The current state of degradation of this ecosystem will certainly affect its prospects for future conservation action.

This study therefore, assessed the influence of soil physicochemical properties on plant species composition and structure in the six fringed communities in the Togo Plateau Forest Reserve so as to contribute to management measures.

The study addressed two research questions: (a) What is the composition of soil of the Togo Plateau Forest Reserve? (b) Does the plant species composition and structure in the TPFR recognizably vary among species along the plateau and across the study communities? If yes- is Soil physicochemical parameters responsible? To answer these questions, a hypothesis is postulated that soil physicochemical parameters are closely linked to species composition and structure in the TPFR in Ghana.

\section{Material and methods}

\subsection{Study Area}

The Togo Plateau Forest Reserve was established by the British Colonial Administration in 1929, in the then TransVolta-Togoland and gazetted in 1931 as a forest reserve in Ghana. The reserve occupies an area of 14.763 hectares, making it the largest in the Volta Region. It lies within longitudes $0^{\circ} 15^{\prime} \mathrm{E}$ and $0^{\circ} 45^{\prime} \mathrm{E}$ and latitudes $6^{\circ} 45^{\prime} \mathrm{N}$ and $7^{\circ} 15^{\prime} \mathrm{N}$ with the elevation between 250 and 2680 m.a.s.l (Figure 1). The reserve is surrounded by several communities which constitute the focus of the study including Hohoe $(\mathrm{HH})$ and Alavanyo (AL) which are located within the Hohoe Municipality of the Volta Regionand Santrokofi (SA) and Akpafu (AK) in the proposed SALL District as well as Bowiri (BO)and Nkonya (NK) in the Biakoye District of the Oti Region all of Ghana.

The Hohoe municipality has a total land area of 1,172 km2, representing 5.6\% of the land area of the Volta Region, and has Hohoe as its capital. The municipality lies in the wet semi-equatorial climatic zone, with annual rainfall of 1016$1210 \mathrm{~mm}$ and 4-5-month dry season between November and April. Temperatures are high throughout the year and range from $26{ }^{\circ} \mathrm{C}$ to about $32{ }^{\circ} \mathrm{C}$. The population of the Municipality in 2010 was 172,950 (Ghana Statistical Service 2010). The Biakoye District, on the other hand, has a total land area of $738.20 \mathrm{~km} 2$, representing about $4.1 \%$ of the total land area of the region. The district capital is Nkonya Ahenkro. The district experiences the wet equatorial rainfall regime with its peak in July and September, respectively. The mean annual rainfall is about $1500 \mathrm{~mm}$. There is a rather short dry season, which is characterized by the cool dry North-East trade winds from early December to mid-March. Temperatures vary between $22^{\circ} \mathrm{C}$ and $34^{\circ} \mathrm{C}$. The district is estimated to have 63,645 people [4]. Major economic activities of the inhabitants include fishing, lumbering, carpentry, blacksmithing, distilling, palm oil extraction and gari processing. 


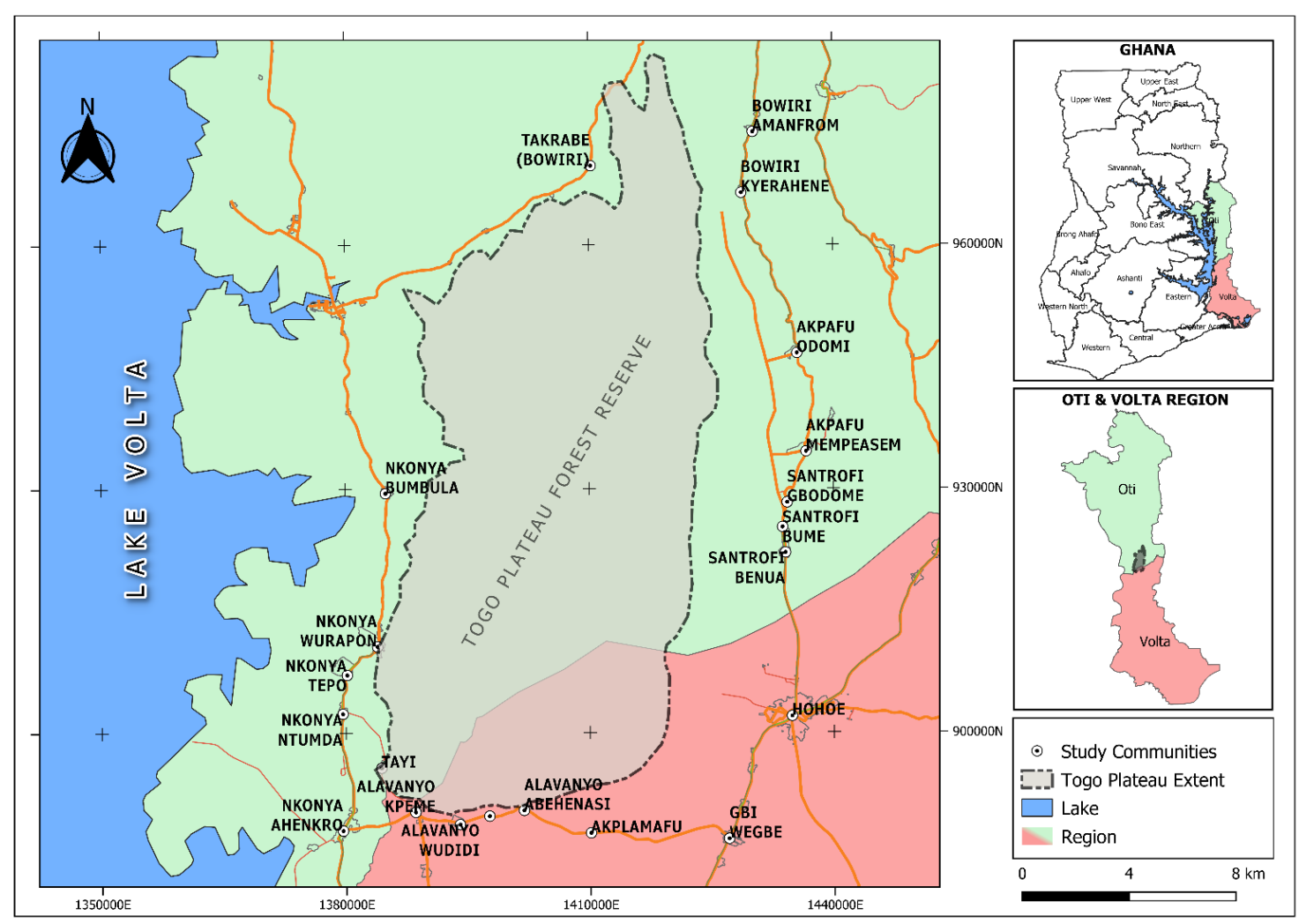

Figure 1 A map of Togo Plateau Forest Reserve in Ghana showing the locations of the study communities.

\subsection{Soil sampling design}

To investigate the influence of soil physicochemical parameters on species composition and structure in the six fringed communities (Hohoe, Alavanyo, Santrokofi, Akpafu, Bowiri, and Nkonya) in the Togo Plateau Forest Reserve in Ghana, composite soil samples (mixing three sub-samples) were collected in mini-pits dug at depths $(0-60 \mathrm{~cm})$ with the help of soil auger and vegetation parameters were determined from the thirty plots (each of dimension $25 \mathrm{~m} \times 25 \mathrm{~m}$ ) that were demarcated in each of the six communities $(n=180)$.The collected samples were analyzed at the Soil Research Institute of Ghana, Analytical Services Division, Kumasi for 16 edaphic variables. Soil samples were air-dried and sifted through a 2-mm mesh and physical and chemical characteristics were determined. The analyses included granulometry (sand, clay and silt contents); active acidity (pH) in water exchangeable acidity (Al); contents of TCa, TMg, TK, Na and available P; BASE SAT; total cation exchange capacity (CEC) including micronutrients (Zn, Fe, Mn, Cu plus ex. acidity); electrical conductivity (EC); organic matter (OM) and organic carbon (OC). The mean value was then calculated for each plot. The soils were classified according to World Reference Base for Soil Resources (WRB) (ISSS Working Group RB 2015) EC (meters).

\subsection{Data Analysis}

The statistical parameters including mean, minimum, maximum, standard deviation and coefficient of variation (CV) of the 16 soil physicochemical parameters was obtained using ANOVA [13]. To compare means of vegetative parameters (density, richness, Shannon Diversity, Evenness and BA) along the plateau and across the study communities, SPSS ( $p>0.05, p>0.01$ ) was used [5]. The influence of soil physico-chemical properties on species composition and structure was determined employing Canonical Correspondence Analysis using R-Software Version 4.0.3 [5].

\section{Results}

\subsection{Variation among the soil physicochemical properties in the TPFR}

The results obtained from Soil properties (pH, OC, TN, OM, TCa, TMg, TK, Na, T.E.B, EX. I SAT, AVI-P1 and \% Sand, \% Clay and \% Silt), statistical parameters and coefficients of variation (CV) were presented (Table 1). The soil of the study area tended to be somewhat weak acidic to neutral, with a pH ranging between 4.17 and 7.06. 
Table 1 Descriptive statistics of soil properties sampled at depth of $(0-60 \mathrm{~cm})$ from the six study sites in the TPFR in Ghana $(\mathrm{n}=180)$.

\begin{tabular}{|l|c|c|c|c|c|}
\hline Soil Physico-chemical property & Mean & Min & Max & Sd & CV (\%) \\
\hline pH & 5.31 & 4.17 & 7.06 & 0.56 & 10.6 \\
\hline OC (\%) & 1.27 & 0.16 & 3.19 & 0.54 & 42.5 \\
\hline TN (\%) & 0.11 & 0.01 & 0.28 & 0.05 & 45.5 \\
\hline OM (\%) & 2.19 & 0.27 & 5.50 & 0.92 & 42 \\
\hline TCa (\%) & 3.11 & 0.43 & 17.04 & 1.92 & 61.7 \\
\hline TMg (\%) & 1.11 & 0.11 & 2.82 & 0.52 & 46.9 \\
\hline TK (\%) & 0.23 & 0.11 & 0.45 & 0.06 & 26.1 \\
\hline Na (cmol/kg) & 0.16 & 0.08 & 0.40 & 0.06 & 37.5 \\
\hline T.E.B (cmol/kg) & 4.61 & 1.16 & 20.71 & 2.45 & 53.2 \\
\hline EX. ACIDITY (cmol/kg) & 0.78 & 0.10 & 1.40 & 0.30 & 38.5 \\
\hline ECEC (cmol/kg) & 5.38 & 1.37 & 22.11 & 2.69 & 50 \\
\hline BASE SAT (\%) & 84.62 & 71.07 & 93.67 & 4.26 & 5.02 \\
\hline AVI-P 1 (ppmP) & 2.69 & 0.34 & 6.70 & 1.24 & 46.1 \\
\hline Sand (\%) & 72.03 & 52.10 & 86.00 & 6.55 & 9.09 \\
\hline Clay (\%) & 12.34 & 5.00 & 26.00 & 3.93 & 31.9 \\
\hline Silt (\%) & 15.43 & 6.00 & 25.47 & 4.09 & 26.5 \\
\hline
\end{tabular}

The coefficient of variation within the physical properties varies from pH 10.6 to total nitrogen (45.5) (Table 1). Estimating variability in terms of CV values for the chemical properties, BASE SAT showed low values (c.v.<15\%), with moderate CV values of (c.v.=34\%-15\%) for TK and a high CV values (c.v.>35\%) for TCa, TMg, Na, T.E.B, EX. ACIDITY and ECEC, AVI-P1(Table 1). The pattern of variability within the mechanical classes was (31.9) for clay, (26.5) for silt and (9.09) for sand. In general, the descriptive statistics showed high variability in soil properties in the study area (Table 1).

\subsection{Soil and vegetation composition along and across the study communities in the TPFR}

The study results showed that there was a significant difference in soil physicochemical parameters across the study communities in the TPFR $\left({ }^{*} \mathrm{p}<0.10,{ }^{* *} \mathrm{P}<0.05,{ }^{* * *} \mathrm{P}<0.01\right.$, Table 2$)$. Table 3 presents similarities and differences in soil physicochemical parameters across the study communities (Significant differences showed by different letters and the same letters are not statistically significantly different from each other at $\left({ }^{*} \mathrm{P}<0.05\right.$; $\left.{ }^{*} \mathrm{P}<0.001\right)$. The degree of correlation among the sixteen soil properties is shown in Table 8. All the soil physicochemical parameters were significantly positively and negatively correlated with each other, indicating similar and opposite spatial distribution patterns respectively. Total Nitrogen (TN) and TP were positively correlated with soil pH, TK however, correlated negatively with $\mathrm{pH}$. The concentrations of $\mathrm{OC}$, TN and TP had no correlation between each other, and therefore no correlation coefficients between OC and TN, OC and TP and for TN and TP, this means that the C:N, C:P and N:P ratios were not constrained (Table 8).

Along the landscape, soil properties including $\mathrm{pH}, \mathrm{OC}$, TN, OM, TCa, TMg, TK, Na, T.E.B, ex. Acidity, ECEC, Base sat, AVI $P(p p m P)$, Sand and Silt were seen to be the drivers of the vegetation (trees, saplings, seedlings) composition and structure based on the first two axes of the CCA $(\mathrm{p}<0.05$, Table 8$)$. The variation and correlations along the landscape include trees $(84 \%, 0.8244$ and 0.6649$)$, saplings (87\%, 0.8051 and 0.6216$)$ and seedlings $(67 \%, 7822$ and 0.6079$)$.

Across the communities fringing the landscape, soil properties including pH, OC, TN, OM, TCa, TMg, TK, Na, T.E.B, ex. Acidity, ECEC, Base sat, AVI - P (ppmP), Sand and Silt were seen to be the drivers of trees composition and structure based on the first two axes of the CCA ( $<<0.05$, Table 9). The variation and correlations across the communities include BO (100\%, 0.997 and 0.989), NK (99.99\%, 0.998 and 0.921), AK (100\%, 0.994 and 0.845), SA (100\%, 0.994 and 0.912), $\mathrm{HH}(99.99 \%, 0.994$ and 0.959$)$ and AL (99.99\%, 0.97 and 0.673$)$ respectively $(\mathrm{p}<0.05$, Table 9$)$. Many of the soil variables that were correlated with these two CCA axes were further strongly and significantly mutually correlated with the first 20 most important trees across the study communities (Appendix 2,3) and vegetation parameters including density (P $=0.000, \mathrm{f}=5.21)$, richness $(\mathrm{P}=0.000, \mathrm{f}=7.71)$, Shannon $(\mathrm{P}=0.000, \mathrm{f}=5.96)$, evenness $(\mathrm{P}=0.000, \mathrm{f}=11.00)$ and $\mathrm{BA}(\mathrm{P}$ $=0.000, \mathrm{f}=6.71$ ) (Table 10). It is only AL which exhibited different patterns showing only sand and silt as having a 
strong influence on the tree distribution (Appendix 2, 3). In the other vein, all the vegetation attributes were seen to be highest for BO, NK and AK and lowest in the SA, HH and AL communities of the plateau (Table 10). A detailed similarities and differences in vegetation attributes across the study communities have been presented (differences are showed by different letters and the same letters show similarity between the communities at $\left(* \mathrm{P}<0.05\right.$; ${ }^{* *} \mathrm{P}<0.001$ ) (Table 11).

With respect to the saplings composition and structure, soil characteristics including $\mathrm{pH}, \mathrm{OC}, \mathrm{TN}, \mathrm{OM}, \mathrm{TCa}, \mathrm{TMg}, \mathrm{TK}, \mathrm{Na}$, T.E.B, ex. Acidity, ECEC, Base sat, Clay and Silt were discovered to have significant influence based on the first two axes of the CCA across the study communities ( $\mathrm{p}<0.05$, Table 10). The variation and correlations across the communities include BO (98\%, 0.9997 and 0.7991), NK (96\%, 0.9979 and 0.6858), AK (20\%, 0.9565 and 0.7916$)$, SA (86\%, 0.9953 and 0.7686$), \mathrm{HH}(66 \%, 0.9983$ and 0.874$)$ and $\mathrm{AL}(44 \%, 0.9767$ and 0.912$)(\mathrm{p}<0.05$, Table 10). Many of the soil variables that were correlated with these two CCA axes were further strongly and significantly mutually correlated with the first 20 most important saplings across the study communities (Appendix 4,5) and vegetation parameters including richness $(P=0.010, f=6.92)$ and Shannon $(P=0.004, f=8.56)$ (Table 10). Except for HH and BO that have insignificant soil correlation with diversity and evenness, all other communities have a significantly soil - vegetation correlations $(\mathrm{p}<0.05$, Appendix 4, 5, Table 10).

With respect to seedlings composition and structure, soil characteristics including $\mathrm{pH}, \mathrm{OC}, \mathrm{TN}, \mathrm{OM}, \mathrm{TCa}, \mathrm{TMg}, \mathrm{TK}, \mathrm{Na}$, T.E.B, ex. Acidity, ECEC, Base sat, AVI - P (ppmP) and Sand had significant influence based on the first two axes of the CCA across the communities $(\mathrm{p}<0.05$, Table 11).The variation and correlations across the communities include BO (91\%, 1.000 and 1.000), NK (84\%, 0.997 and 0.55), AK (74\%, 0.998 and 0.972), SA (67\%, 0.975 and 0.944), HH (55\%, 0.992 and 0.817$)$ and AL (54\%, 0.992 and 0.78$)$ respectively $(\mathrm{p}<0.05$, Table 11). Many of the soil variables that correlated with these two CCA axes were further strongly and significantly mutually correlated with the first 20 most important seedlings listed across the study communities (Appendix 6, 7) and vegetation parameters including density $(\mathrm{P}=0.000, \mathrm{f}=44.3)$ and richness $(\mathrm{P}=0.014, \mathrm{f}=7.71)$ (Table 10). Almost all the communities exhibited a similar pattern of sapling-soil relationship with the exception of NK which exhibited different pattern ( $p<0.05$, Appendix 6, 7, Table 11).

\subsection{Effect of soil physicochemical on vegetation composition and structure}

In general, 16 soil variables including (pH, OC, TN, OM, TCa, TMg, TK, Na, T.E.B, ex. Acidity, ECEC, Base sat, AVI - P (ppmP), Sand, Clay and Silt) had significant influence on vegetation (trees, saplings, seedlings) composition and structure across the six study communities (Table 8). These results suggest that soil plays a more important role in the determination of composition and structure of vegetations in plateau forest habitats.

In relation to the study communities, 15 Soil characteristics (pH, OC, TN, OM, TCa, TMg, TK, Na, T.E.B, ex. Acidity, ECEC, Base sat, AVI - P (ppmP), Sand and Silt) significantly influenced tree distribution in Axis 1 in the BO, NK, AK, SA and HH forest formation habitats (Table 9). However, this degree of influence varies across these communities partly due to different gradients created by these 15 Soil characteristics. The distinct interaction of the 15 soil variables with each other on Axis 1 and Axis 2 (Table 9) has accounted for all the vegetation parameters (density, richness, shannon, evenness and BA) values for trees decreasing in the order from BO, NK, AK, SA, HH and AL (Table 10). The first 20 most important trees and their correlations with the soil variables across the study communities have been presented (Figure $2,3)$.

Among the saplings, more than 13 soil characteristics (pH, OC, TN, OM, TCa, TMg, TK, Na, T.E.B, ex. Acidity, ECEC, Base sat and Silt) influenced vegetation composition and structure significantly by Axis 1 in BO, NK, HH and AL forest formation habitats (Table 10). Akpafu (AK) however, is distinct and did not show any interaction with any soil characteristics on any Axis in its forest formation habitats (Table 10). Similarly, this trend of influence accounted for the vegetation parameters including (richness and shannon) values for saplings decreasing in the order from $\mathrm{BO}, \mathrm{NK}$, AK, SA, HH and AL (Table 10). No significant difference was however seen in density and evenness across the communities. (Table 10). The first 20 most important saplings and their correlations with the soil variables across the study communities have been presented (Figure 4 and $2 \mathrm{~b}$ ).

Among the seedlings, more than 13 soil characteristics (pH, OC, TN, OM, TCa, TMg, TK, Na, ex. Acidity, ECEC, Base sat, $\mathrm{AVI}-\mathrm{P}$ (ppmP) and Sand) influenced vegetation composition and structure significantly by Axis 1 in BO, AK, HH and AL forest formation habitats (Table 11). Nkonya (NK) however, is distinct and did not show any interaction with any soil characteristics on any Axis in its forest formation habitats (Table 11). This trend of influence accounted for density and shannon parameters showing a significant difference across the communities (Table 11). The first 20 most important seedlings and their correlations with the soil variables across the study communities have been presented (Figure 6, 7). 

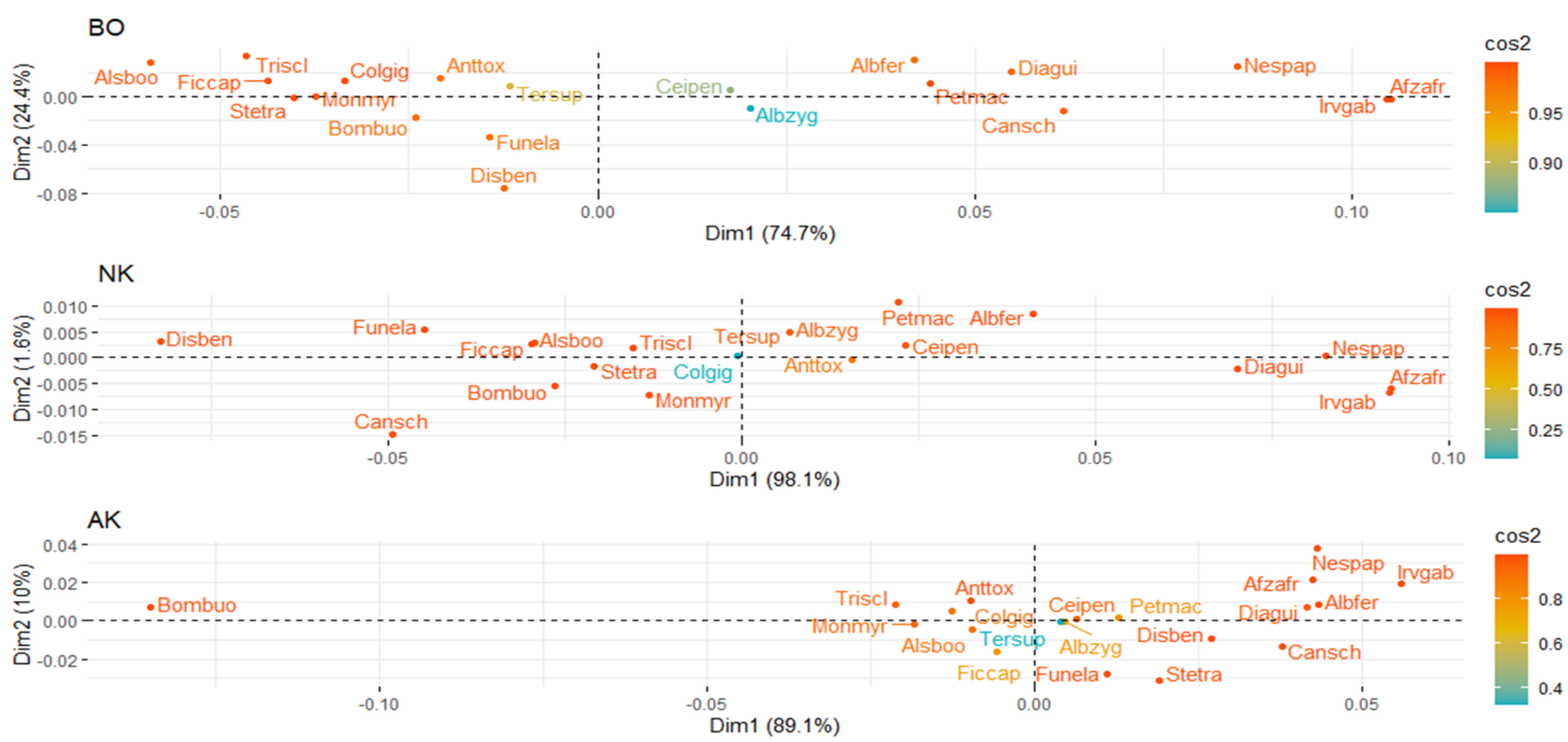

Figure 2 Canonical correspondence analysis (CCA) displaying relation of the 20 most abundant tree species with the following 15 identified soil driving variables: (pH, OC, TN, OM, TCa, TMg, TK, Na, T.E.B, ex. Acidity, ECEC, Base sat, AVI - P (ppmP), Sand and Silt) in the BO, NK and AK communities in the TPFR in Ghana. 
SA
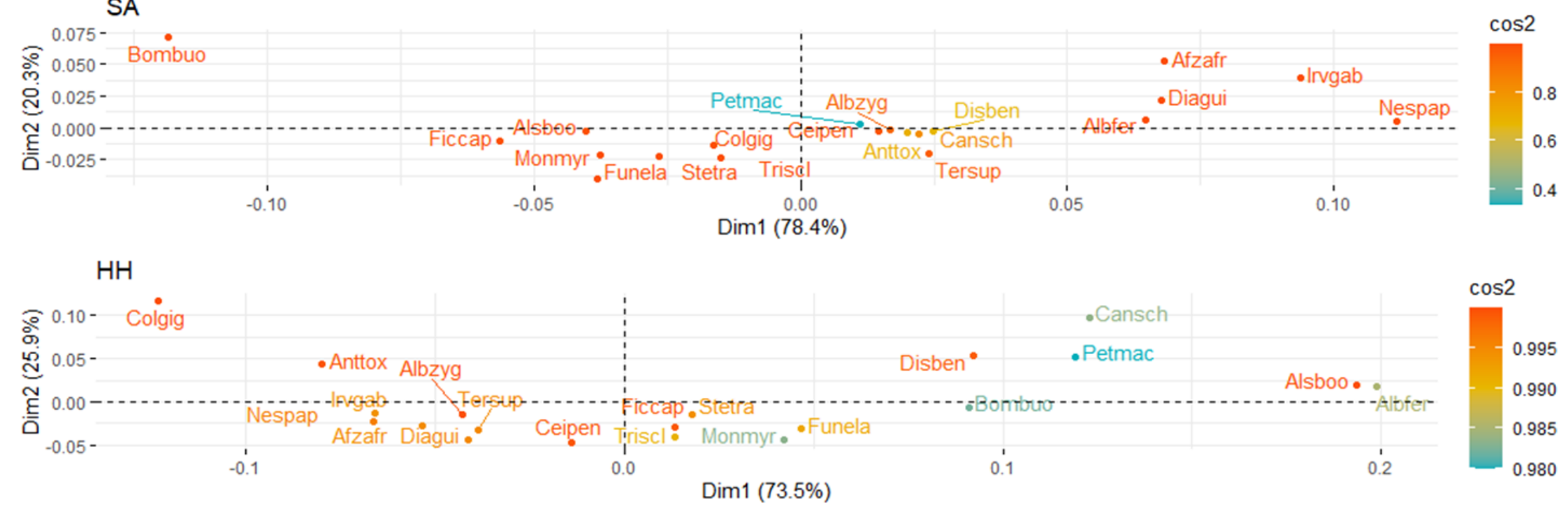

$\mathrm{AL}$

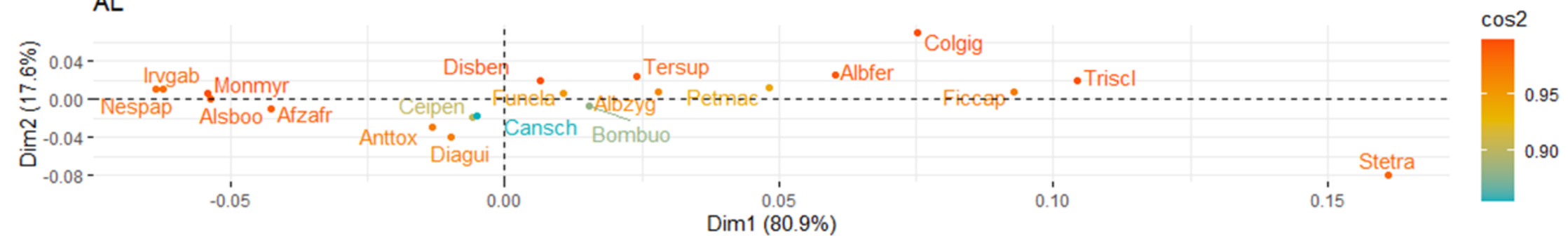

Figure 3 Canonical correspondence analysis (CCA) displaying relation of the 20 most abundant tree species with the following 15 identified soil driving variables: (pH, OC, TN, OM, TCa, TMg, TK, Na, T.E.B, ex. Acidity, ECEC, Base sat, AVI - P (ppmP), Sand and Silt) in the SA, HH and AL communities in the TPFR in Ghana. 
BO
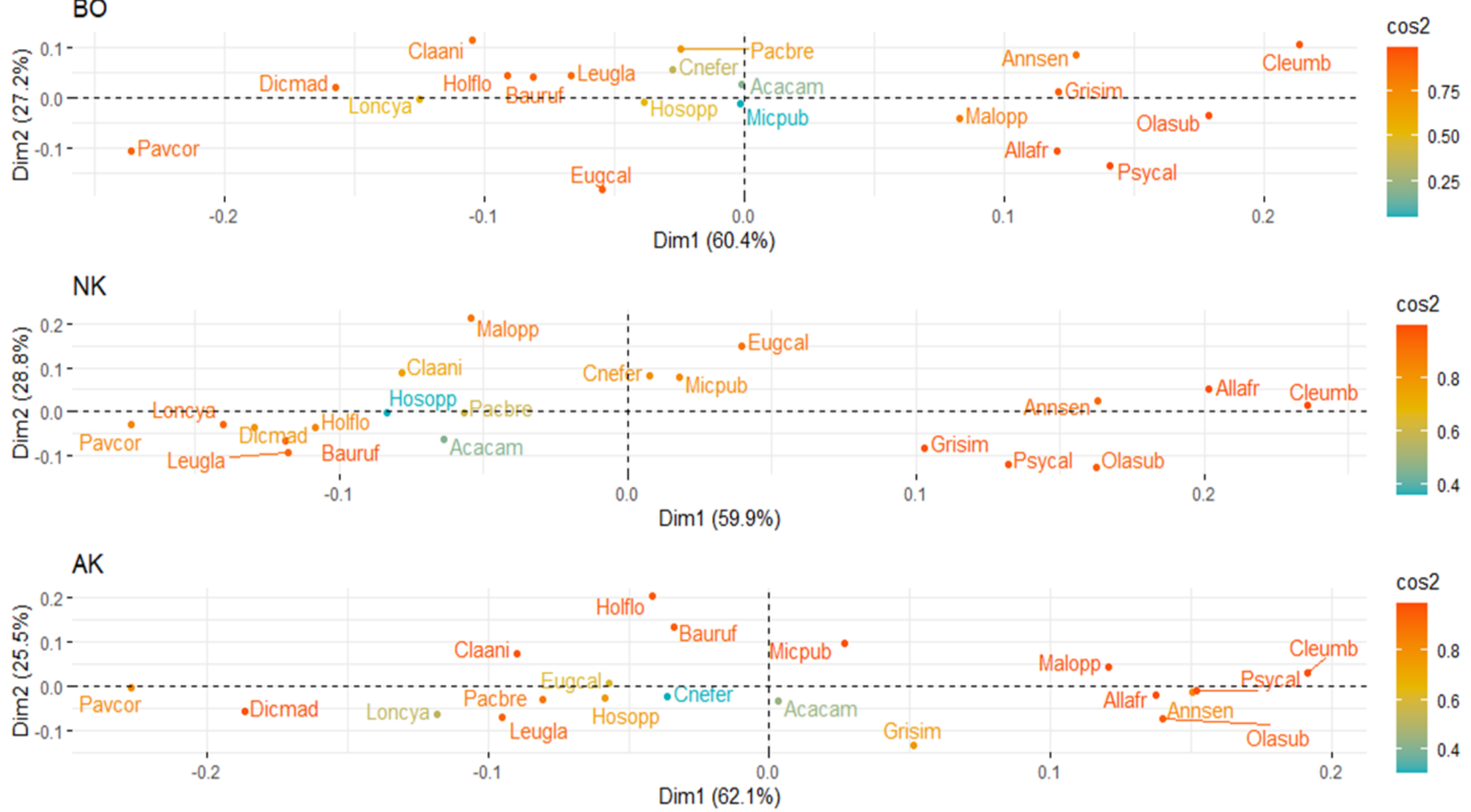

Figure 4 Canonical correspondence analysis (CCA) displaying relation of the 20 most abundant saplings with the following 13 identified soil driving variables: (pH, OC, TN, OM, TCa, TMg, TK, Na, T.E.B, ex. Acidity, ECEC, Base sat and Silt) in the BO, NK and AK communities in the TPFR in Ghana. 
Table 2 Mean $( \pm$ SD) properties of soils sampled at depth of $(0-60 \mathrm{~cm})$ from the six study sites in the Togo Plateau Forest Reserve

(Analyzed by Soil Research Institute of Ghana, Analytical Services Division, Kumasi)

\begin{tabular}{|c|c|c|c|c|c|c|c|c|c|c|c|c|c|c|}
\hline \multirow{2}{*}{ Variable } & BO & & NK & & AK & & SA & & HH & & AL & & & \\
\hline & Mean & SD & Mean & SD & Mean & SD & Mean & SD & Mean & SD & Mean & SD & F Test & P-Value \\
\hline $\mathrm{pH}$ & 5.357 & 0.626 & 5.39 & 0.668 & 5.783 & 0.223 & 5.206 & 0.37 & 5.365 & 0.44 & 5.754 & 0.38 & 4.887 & $0.000^{* * *}$ \\
\hline OC (\%) & 1.756 & 0.531 & 1.826 & 0.535 & 1.187 & 0.395 & 1.469 & 0.449 & 1.224 & 0.53 & 1.209 & 0.369 & 7.417 & $0.000^{* * *}$ \\
\hline $\mathrm{TN}(\%)$ & 0.151 & 0.046 & 0.158 & 0.046 & 0.103 & 0.033 & 0.128 & 0.039 & 0.106 & 0.05 & 0.105 & 0.031 & 7.349 & $0.000^{* * *}$ \\
\hline OM (\%) & 3.024 & 0.919 & 3.148 & 0.922 & 2.047 & 0.682 & 2.535 & 0.775 & 2.111 & 0.91 & 2.082 & 0.635 & 7.387 & $0.000^{* * *}$ \\
\hline ТCa (\%) & 2.223 & 1.031 & 1.825 & 1.278 & 2.137 & 1.344 & 2.272 & 1.707 & 3.342 & 0.97 & 2.842 & 0.733 & 4.103 & $0.002^{* * *}$ \\
\hline $\operatorname{TMg}(\%)$ & 0.706 & 0.427 & 0.909 & 0.265 & 1.076 & 0.194 & 0.882 & 0.33 & 0.877 & 0.49 & 1.084 & 0.715 & 2.09 & $0.072^{*}$ \\
\hline TK (\%) & 0.186 & 0.032 & 0.198 & 0.049 & 0.22 & 0.034 & 0.194 & 0.037 & 0.225 & 0.04 & 0.212 & 0.043 & 3.02 & $0.013^{* *}$ \\
\hline $\mathrm{Na}(\mathrm{cmol} / \mathrm{kg})$ & 0.129 & 0.032 & 0.124 & 0.021 & 0.191 & 0.033 & 0.142 & 0.029 & 0.141 & 0.02 & 0.146 & 0.037 & 12.79 & $0.000^{* * *}$ \\
\hline T.E.B (cmol/kg) & 3.243 & 1.512 & 3.055 & 1.585 & 3.625 & 1.593 & 3.49 & 2.065 & 4.584 & 1.51 & 4.284 & 1.504 & 2.668 & $0.026^{* *}$ \\
\hline EX. ACIDITY (cmol/kg) & 0.552 & 0.213 & 0.501 & 0.157 & 0.76 & 0.246 & 0.825 & 0.175 & 0.702 & 0.33 & 0.762 & 0.306 & 5.442 & $0.000^{* * *}$ \\
\hline ECEC $(\mathrm{cmol} / \mathrm{kg})$ & 3.796 & 1.703 & 3.556 & 1.705 & 4.386 & 1.826 & 4.316 & 2.221 & 5.287 & 1.84 & 5.045 & 1.803 & 2.652 & $0.026^{* *}$ \\
\hline BASE SAT (\%) & 85.237 & 3.361 & 84.928 & 4.451 & 82.126 & 2.991 & 77.966 & 6.078 & 87.22 & 1.91 & 85.133 & 1.52 & 15.52 & $0.000^{* * *}$ \\
\hline AVI-P 1 (ppmP) & 3.404 & 1.335 & 4.526 & 0.622 & 2.895 & 0.546 & 3.077 & 0.633 & 1.333 & 0.48 & 2.139 & 0.99 & 35.14 & $0.000^{* * *}$ \\
\hline Sand (\%) & 72.087 & 5.282 & 75.82 & 5.865 & 74.316 & 4.839 & 73.655 & 6.857 & 70.65 & 8.68 & 69.871 & 3.557 & 2.812 & $0.020^{* * *}$ \\
\hline Clay (\%) & 11.854 & 2.656 & 10.277 & 3.894 & 10.006 & 3.34 & 11.771 & 3.701 & 13.54 & 5 & 12.959 & 2.243 & 3.08 & $0.012^{* *}$ \\
\hline Silt (\%) & 15.964 & 3.887 & 13.697 & 2.868 & 15.526 & 2.787 & 14.074 & 4.503 & 14.96 & 4.43 & 17.225 & 3.734 & 2.363 & $0.044^{* *}$ \\
\hline
\end{tabular}


SA

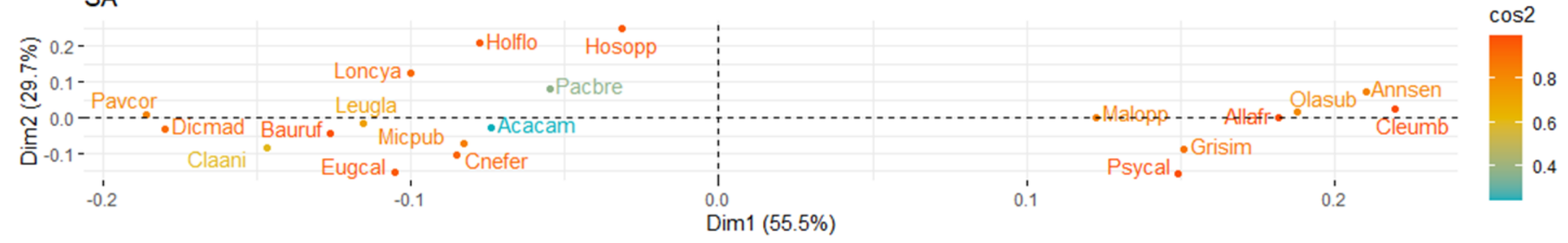

$\mathrm{HH}$

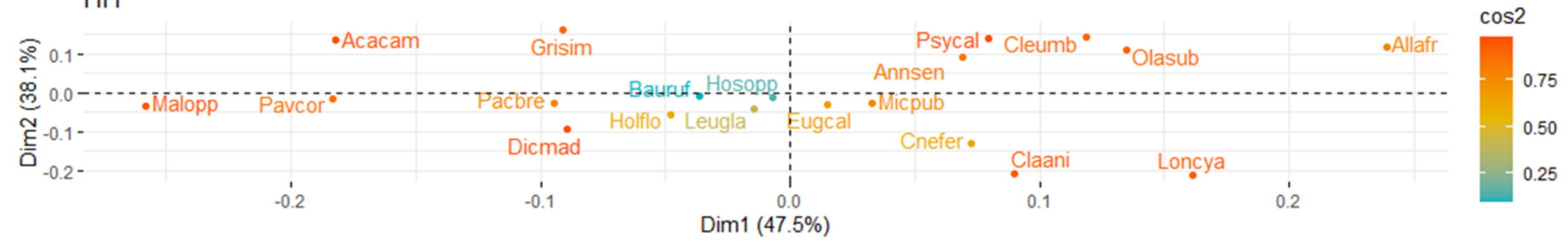

$\mathrm{AL}$

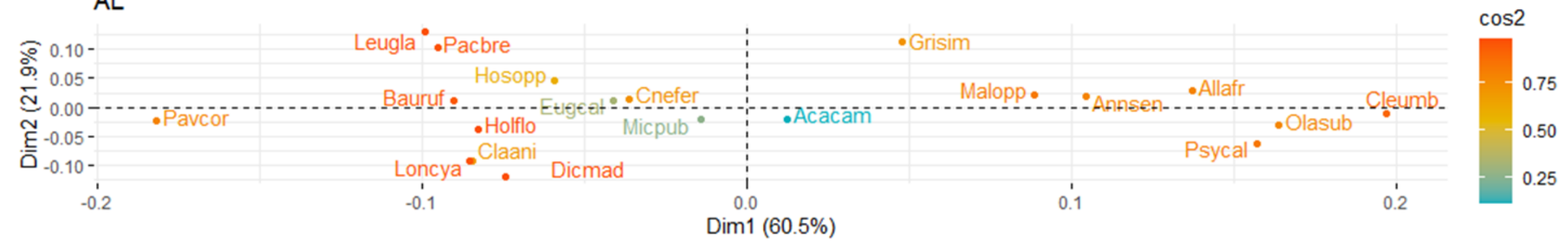

Figure 5 Canonical correspondence analysis (CCA) displaying relation of the 20 most abundant saplings with the following 13 identified soil driving variables: (pH, OC, TN, OM, TCa, TMg, TK, Na, T.E.B, ex. Acidity, ECEC, Base sat and Silt) in the SA, HH and AL communities in the TPFR in Ghana. 
Table 3 Mean $( \pm$ SD) properties of soils sampled at depth of $(0-60 \mathrm{~cm})$ from the six study sites in the TPFR (Analyzed by Soil Research Institute of Ghana, Analytical Services Division, Kumasi)

\begin{tabular}{|c|c|c|c|c|c|c|c|}
\hline Soil properties & BO & NK & AK & SA & $\mathrm{HH}$ & AL & $p$-value \\
\hline $\mathrm{PH}$ & $5.16 \pm 0.67 a$ & $5.14 \pm 0.70 \mathrm{a}$ & $5.68 \pm 0.27 b$ & $5.06 \pm 0.43 a$ & $5.17 \pm 0.49 a$ & $5.63 \pm 0.37 b$ & $<0.0001^{* *}$ \\
\hline OC (\%) & $1.58 \pm 0.52 \mathrm{c}$ & $1.60 \pm 0.56 c$ & $1.06 \pm 0.38 \mathrm{a}$ & $1.32 \pm 0.45 b$ & $0.97 \pm 0.58 a$ & $1.09 \pm 0.35 \mathrm{ab}$ & $<0.0001^{* *}$ \\
\hline $\mathrm{TN}(\%)$ & $0.14 \pm 0.05 c$ & $0.14 \pm 0.05 c$ & $0.09 \pm 0.03 a$ & $0.11 \pm 0.04 \mathrm{~b}$ & $0.08 \pm 0.05 a$ & $0.09 \pm 0.03 \mathrm{ab}$ & $<0.0001^{* *}$ \\
\hline OM (\%) & $2.73 \pm 0.90 c$ & $2.76 \pm 0.96 c$ & $1.83 \pm 0.65 a$ & $2.27 \pm 0.77 b$ & $1.67 \pm 1.01 \mathrm{a}$ & $1.88 \pm 0.60 \mathrm{ab}$ & $<0.0001^{* *}$ \\
\hline TCa (\%) & $2.64 \pm 1.21 \mathrm{a}$ & $2.52 \pm 1.57 a$ & $2.72 \pm 6.65 a$ & $2.99 \pm 1.88 \mathrm{ab}$ & $4.07 \pm 1.73 c$ & $3.71 \pm 2.73 \mathrm{bc}$ & $0.0046^{* *}$ \\
\hline TMg (\%) & $0.89 \pm 0.47 a$ & $1.04 \pm 0.32 \mathrm{ab}$ & $1.17 \pm 0.24 \mathrm{bc}$ & $1.02 \pm 0.39 \mathrm{ab}$ & $1.15 \pm 0.60 \mathrm{bc}$ & $1.38 \pm 0.81 c$ & $0.0081^{* *}$ \\
\hline TK $(\%)$ & $0.20 \pm 0.04 a$ & $0.23 \pm 0.07 \mathrm{abc}$ & $0.24 \pm 0.05 b c$ & $0.21 \pm 0.06 \mathrm{ab}$ & $0.25 \pm 0.07 c$ & $0.24 \pm 0.07 \mathrm{bc}$ & $0.0137^{*}$ \\
\hline $\mathrm{Na}(\mathrm{cmol} / \mathrm{kg})$ & $0.14 \pm 0.04 \mathrm{ab}$ & $0.13 \pm 0.02 \mathrm{a}$ & $0.21 \pm 0.06 \mathrm{~d}$ & $0.16 \pm 0.05 b c$ & $0.16 \pm 0.06 \mathrm{bc}$ & $0.17 \pm 0.06 \mathrm{c}$ & $<0.0001^{* *}$ \\
\hline T.E.B (cmol/kg) & $3.87 \pm 1.74 a$ & $3.92 \pm 1.95 a$ & $4.35 \pm 1.99 \mathrm{ab}$ & $4.39 \pm 2.34 \mathrm{ab}$ & $5.63 \pm 2.42 c$ & $5.49 \pm 3.43 \mathrm{bc}$ & $0.0095^{* *}$ \\
\hline EX. ACIDITY (cmol/kg) & $0.62 \pm 0.21 \mathrm{a}$ & $0.57 \pm 0.17 \mathrm{a}$ & $0.84 \pm 0.25 b$ & $0.90 \pm 0.20 \mathrm{~b}$ & $0.85 \pm 0.38 b$ & $0.88 \pm 0.33 b$ & $<0.0001^{* *}$ \\
\hline ECEC $(\mathrm{cmol} / \mathrm{kg})$ & $4.49 \pm 1.93 a$ & $4.48 \pm 2.10 \mathrm{a}$ & $5.19 \pm 2.23 \mathrm{ab}$ & $5.29 \pm 2.53 \mathrm{ab}$ & $6.48 \pm 2.77 b$ & $6.37 \pm 3.69 b$ & $0.006^{* *}$ \\
\hline Basesat (\%) & $85.72 \pm 3.00 c$ & $86.19 \pm 4.16 c$ & $82.94 \pm 2.93 b$ & $80.28 \pm 6.02 c$ & $87.09 \pm 1.76 \mathrm{c}$ & $85.49 \pm 2.13 c$ & $<0.0001^{* *}$ \\
\hline AVI-BRAY 1 (ppmP) & $3.03 \pm 1.36 \mathrm{~d}$ & $4.31 \pm 0.61 c$ & $2.53 \pm 0.85 c$ & $2.85 \pm 0.62 \mathrm{~cd}$ & $1.35 \pm 0.49 a$ & $2.10 \pm 0.86 b$ & $0.0001^{* *}$ \\
\hline Sand (\%) & $71.67 \pm 6.34 \mathrm{ab}$ & $74.89 \pm 6.46 b$ & $72.49 \pm 6.77 \mathrm{ab}$ & $72.76 \pm 6.93 \mathrm{ab}$ & $70.05 \pm 7.75 a$ & $70.30 \pm 3.57 a$ & $0.0459^{*}$ \\
\hline Clay (\%) & $12.18 \pm 2.92 \mathrm{ab}$ & $10.70 \pm 4.15 a$ & $11.08 \pm 3.97 \mathrm{a}$ & $13.11 \pm 4.41 b c$ & $14.34 \pm 4.55 c$ & $12.62 \pm 2.11 \mathrm{abc}$ & $0.003^{* *}$ \\
\hline Silt (\%) & $16.06 \pm 4.33 b c$ & $14.35 \pm 3.02 \mathrm{ab}$ & $16.17 \pm 3.64 b c$ & $13.70 \pm 4.71 \mathrm{a}$ & $15.05 \pm 4.24 \mathrm{ab}$ & $17.23 \pm 3.64 c$ & $0.0081^{* *}$ \\
\hline
\end{tabular}

Significant differences showed by different letters and the same letters are not statistically significantly different from each other at $\left({ }^{*} \mathrm{P}<0.05\right.$; $\left.{ }^{* *} \mathrm{P}<0.001\right)$. 
World Journal of Advanced Research and Reviews, 2020, 08(03), 204-227

Table 8 Pearson's correlation coefficient values showing relationship among soil physicochemical properties in the TPFR in Ghana

\begin{tabular}{|c|c|c|c|c|c|c|c|c|c|c|c|c|c|c|c|c|c|}
\hline & & 1 & 2 & 3 & 4 & 5 & 6 & 7 & 8 & 9 & 10 & 11 & 12 & 13 & 14 & 15 & 16 \\
\hline 1 & pH & 1.0000 & & & & & & & & & & & & & & & \\
\hline 2 & OC & $0.5492^{* * *}$ & 1.0000 & & & & & & & & & & & & & & \\
\hline 3 & TN & $0.5514^{* * *}$ & $0.9981^{* * *}$ & 1.0000 & & & & & & & & & & & & & \\
\hline 4 & OM & $0.5494^{* * *}$ & 1.0000 & $0.9981^{* * *}$ & 1.0000 & & & & & & & & & & & & \\
\hline 5 & TCa & $-\overline{0.6784^{* * *}}$ & 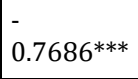 & $\overline{-} .7699^{* * *}$ & $-\overline{0.7694 * * *}$ & 1.0000 & & & & & & & & & & & \\
\hline 6 & TMg & $-\overline{0.5929 * * *}$ & 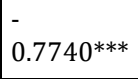 & $-\overline{0.7733^{* * *}}$ & $-\overline{0.7743^{* * *}}$ & $0.6776^{* * *}$ & 1.0000 & & & & & & & & & & \\
\hline 7 & TK & 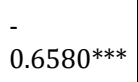 & $-\overline{0.8699 * * *}$ & $-\overline{0.8690^{* * *}}$ & $0.8701^{* * *}$ & $0.8464^{* * *}$ & $\begin{array}{l}0.8601^{* *} \\
*\end{array}$ & 1.0000 & & & & & & & & & \\
\hline 8 & $\mathrm{Na}$ & 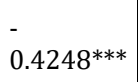 & $\begin{array}{l} \\
0.7972^{* * *}\end{array}$ & $-\overline{0.7959^{* * *}}$ & $-\overline{0.7974^{* * *}}$ & $0.6376^{* * *}$ & $\begin{array}{l}0.8055^{* *} \\
*\end{array}$ & $0.8081^{* * *}$ & 1.0000 & & & & & & & & \\
\hline 9 & T.E.B & $-\overline{0.6994^{* * *}}$ & $-\overline{0.8295^{* * *}}$ & $\overline{0.8302^{* * *}}$ & $-\overline{0.8302^{* * *}}$ & $0.9765^{* * *}$ & $\begin{array}{l}0.8197^{* *} \\
*\end{array}$ & $0.9149^{* * *}$ & $0.7409 * * *$ & 1.0000 & & & & & & & \\
\hline 10 & Acidity & $\begin{array}{l} \\
0.5751^{* * *}\end{array}$ & 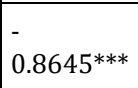 & $-\overline{0.8596^{* * *}}$ & $0.8646^{* * *}$ & $0.7176^{* * *}$ & $\begin{array}{l}0.8479 * * \\
*\end{array}$ & $0.8165^{* * *}$ & $0.7988^{* * *}$ & $0.8089 * * *$ & 1.0000 & & & & & & \\
\hline 11 & ECEC & $-\overline{0.6985^{* * *}}$ & $-\overline{0.8537^{* * *}}$ & $-\overline{0.8537^{* * *}}$ & $0.8543^{* * *}$ & $0.9630^{* * *}$ & $\begin{array}{l}0.8428^{* *} \\
*\end{array}$ & $0.9225^{* * *}$ & $0.7663^{* * *}$ & $0.9966^{* * *}$ & $0.8545^{* * *}$ & 1.0000 & & & & & \\
\hline 12 & Base sat. & -0.1377 & -0.0538 & -0.0620 & -0.0550 & $0.4940^{* * *}$ & 0.0806 & $0.2572^{* *}$ & 0.0502 & $0.4054^{* * *}$ & $-0.1712^{*}$ & $0.3341^{* * *}$ & 1.0000 & & & & \\
\hline 13 & $\begin{array}{ll}\text { Avi-Bray } \quad 1 \\
\text { (ppmP) }\end{array}$ & $0.2521^{* * *}$ & $0.6179^{* * *}$ & $0.6240^{* * *}$ & $0.6182^{* * *}$ & $-\overline{0.6246^{* * *}}$ & 0.2973** & $-\overline{0.4902^{* * *}}$ & 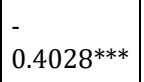 & $-\overline{0.5758^{* * *}}$ & 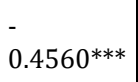 & $-\overline{0.5726^{* * *}}$ & $-\overline{0.2532^{* *}}$ & 1.0000 & & & \\
\hline 14 & Sand & 0.0620 & $0.2239 * *$ & $0.2200^{* *}$ & $0.2233^{* *}$ & $-0.2500^{* *}$ & -0.0712 & $-0.1738^{*}$ & -0.0821 & $-0.2153^{* *}$ & $-0.1605^{*}$ & $-0.2127^{* *}$ & -0.1169 & $0.2841^{* *}$ & 1.0000 & & \\
\hline 15 & Clay & -0.0478 & -0.1136 & -0.1086 & -0.1131 & $0.1578^{*}$ & 0.0076 & 0.0855 & -0.0179 & 0.1236 & 0.0417 & 0.1151 & 0.1244 & $0.2493^{* *}$ & $0.7235^{* * *}$ & 1.0000 & \\
\hline 16 & Silt & 0.0194 & $-0.1997 * 8$ & -0.2012 & -0.1997 & $0.1780^{*}$ & 0.0446 & 0.1244 & 0.1101 & 0.1530 & 0.1336 & 0.1539 & 0.0730 & -0.1846 & \begin{tabular}{|l|} 
\\
$0.7997^{* * *}$
\end{tabular} & $\begin{array}{l}0.2279 * \\
*\end{array}$ & 1.0000 \\
\hline
\end{tabular}


BO
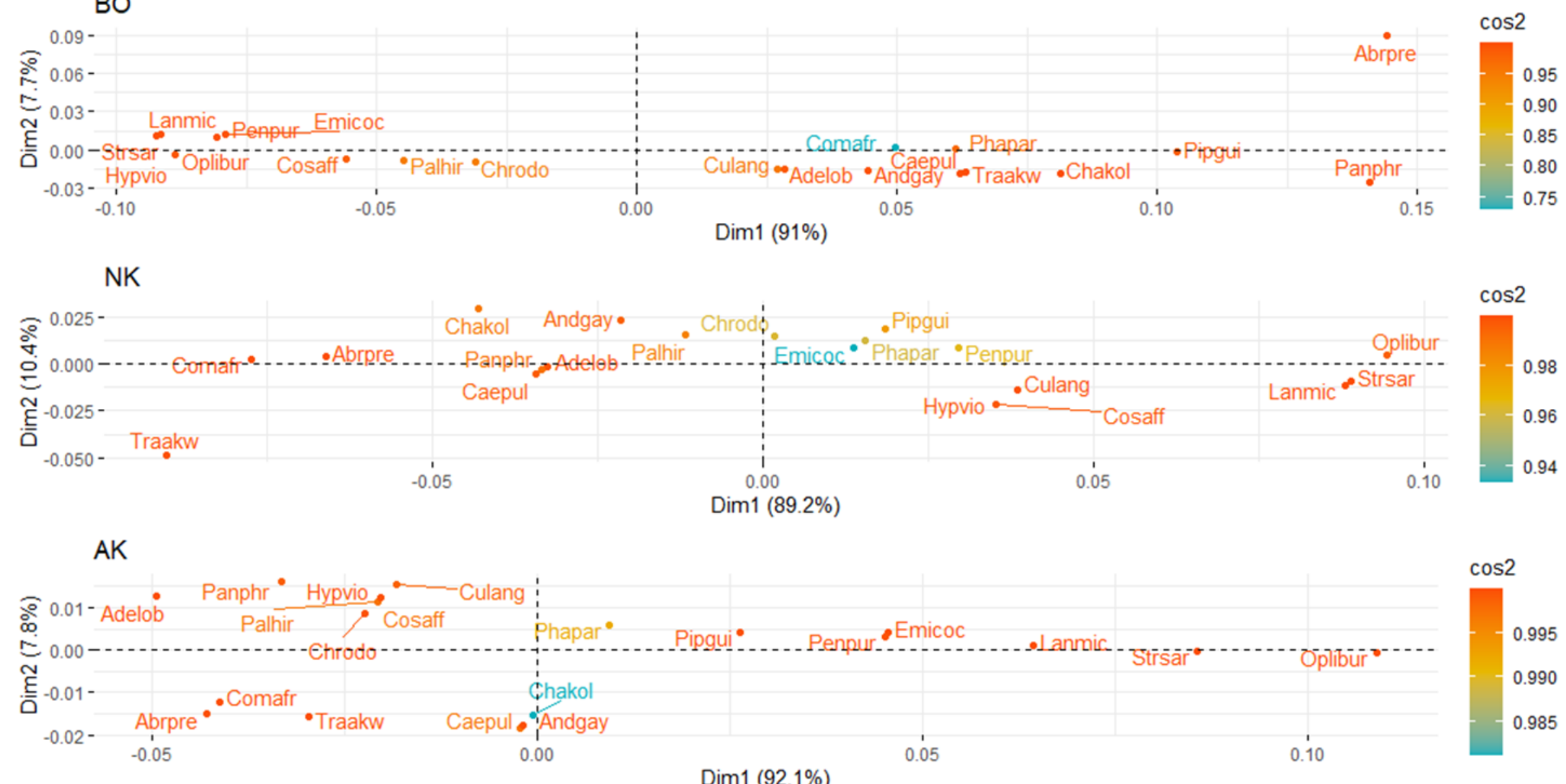

Figure 6 Canonical correspondence analysis (CCA) displaying relation of the 20 most abundant seedlings with the following 13 identified soil driving variables: (pH, OC, TN, OM, TCa, TMg, TK, Na, ex. Acidity, ECEC, Base sat, AVI - P (ppmP) and Sand) in the SA, HH and AL communities in the TPFR in Ghana. 


\section{SA}
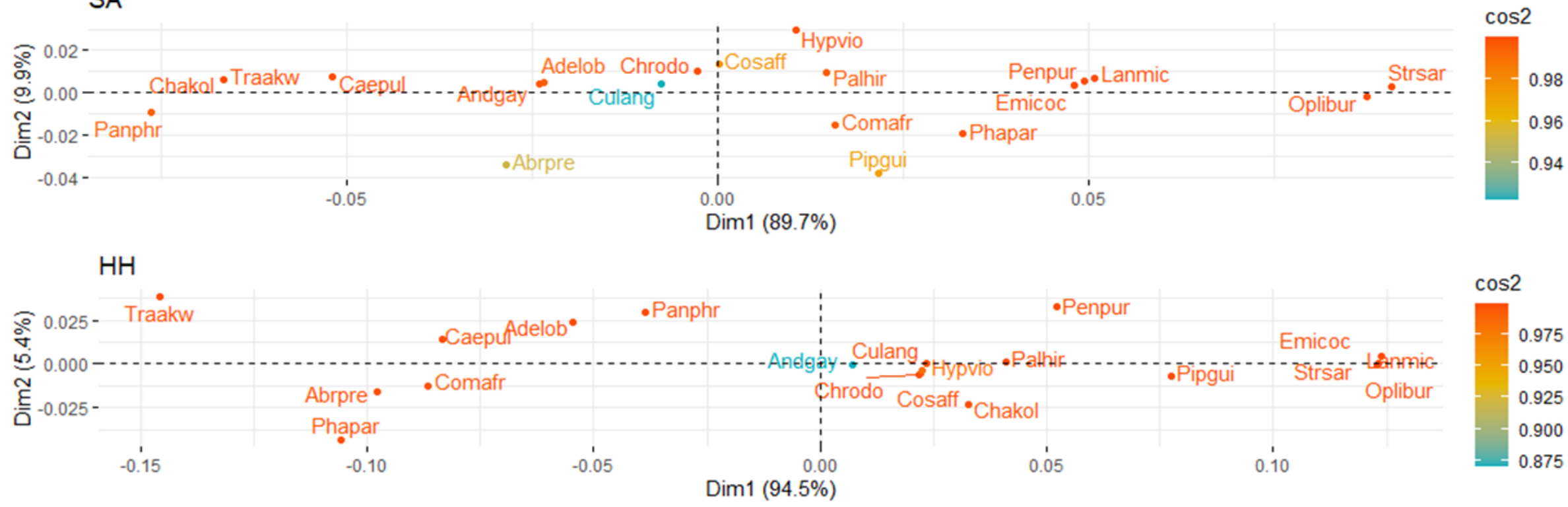

$\mathrm{AL}$

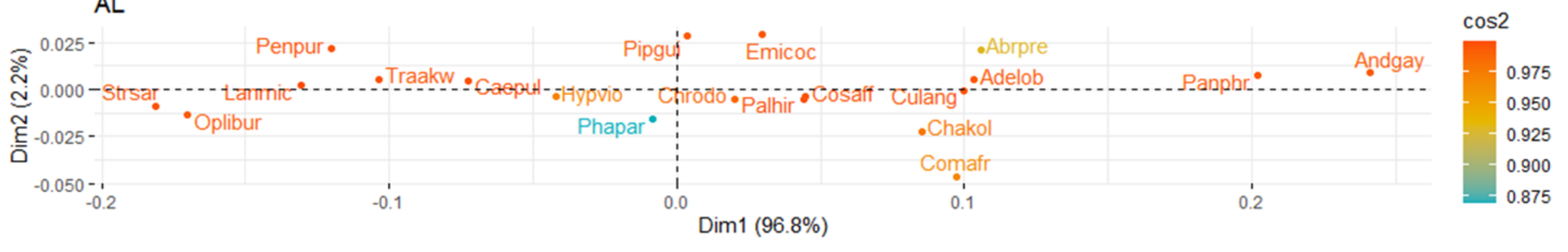

Figure 7 Canonical correspondence analysis (CCA) displaying relation of the 20 most abundant seedlings with the following 13 identified soil driving variables: (pH, OC, TN, OM, TCa, TMg, TK, Na, ex. Acidity, ECEC, Base sat, AVI - P (ppmP) and Sand) in the SA, HH and AL communities in the TPFR in Ghana. 
Table 9 List of the first 20 most important Trees, Saplings and Seedlings and their abbreviations (abbr) in the TPFR in Ghana

\begin{tabular}{|c|c|c|c|c|c|}
\hline Tree & Abbr & Saplings & Abbr & Seedlings & Abbr \\
\hline Ceiba pentandra & Ceipen & Acacia camerunensis & Acacam & Chromolaena odorata & Chrodo \\
\hline Albizia zygia & Albzyg & Microdesmis puberula & Micpub & Palisota hirsuta & Palhir \\
\hline Terminalia superba & Tersup & Cnestis ferruginea & Cnefer & Costus affer & Cosaff \\
\hline Antiaris toxicaria & Anttox & Eugenia calophylloides & Eugcal & Hypselodelphys violacea & Hypvio \\
\hline Cola gigantea & Colgig & Hoslundia opposita & Hosopp & Culcasia angolensis & Culang \\
\hline Triplochiton scleroxylon & Triscl & Pachystela brevipes & Pacbre & Adenia lobata & Adelob \\
\hline Ficus capensis & Ficcap & Leucaena glaca & Leugla & Panicum phragmitoides & Panphr \\
\hline Alstonia boonei & Alsboo & Bauhinia rufescens & Bauruf & Caesalpinia benthamiana & Caeben \\
\hline Sterculia tragacantha & Stetra & Holarrhena floribunda & Holflo & Andropogon gayanus & Andgay \\
\hline Monodora myristica & Monmyr & Clausena anisata & Claani & Tragia akwapimensis & Traakw \\
\hline Funtumia elastica & Funela & Lonchocarpus cyanescens & Loncya & Chassalia kolly & Chakol \\
\hline Bombax buonopozense & Bombuo & Dichapetalum madagascariense & Dicmad & Abrus precatorius & Abrpre \\
\hline Distemonanthus benthamianus & Disben & Pavetta corymbosa & Pavcor & Commelina africana & Comafr \\
\hline Canarium schweinfurthii & Cansch & Mallotus oppositifolia & Malopp & Phaylopsis parviflora & Phapar \\
\hline Petersianthus macrocarpus & Petmac & Griffonia simplicifolia & Grisim & Piper guineense & Pipgui \\
\hline Albizia ferruginea & Albfer & Annona senegalensis & Annsen & Emilia coccinea & Emicoc \\
\hline Dialium guineense & Diagui & Allophylus africanus & Allafr & Pennisetum purpureum & Penpur \\
\hline Afzelia africana & Afzafr & Psychotria calva & Psycal & Landolphia micrantha & Lanmic \\
\hline Irvingia gabonensis & Irvgab & Olax subscorpioides & Olasub & Strophanthus sarmentosus & Strsar \\
\hline Nesogordonia papaverifera & Nespap & Clerodendron umbellatum & Cleumb & Oplismenus burmannii & Oplbur \\
\hline
\end{tabular}


Table 10 ANOVA of Plant Species Composition and Structure in the Six Fringe Communities in the TPFR in Ghana.

\begin{tabular}{|c|c|c|c|c|c|c|c|c|c|c|c|c|c|c|}
\hline \multirow{2}{*}{ Variable } & \multicolumn{2}{|l|}{ BO } & \multicolumn{2}{|l|}{ NK } & \multicolumn{2}{|l|}{ AK } & \multicolumn{2}{|l|}{ SA } & \multicolumn{2}{|l|}{ HH } & \multicolumn{2}{|l|}{ AL } & \multirow{2}{*}{ F test } & \multirow{2}{*}{ P-Value } \\
\hline & Mean & SD & Mean & SD & Mean & SD & Mean & SD & Mean & SD & Mean & SD & & \\
\hline \multicolumn{15}{|l|}{ Trees } \\
\hline Density & 44.9 & 9.93 & 43.5 & 5.8 & 41.6 & 7.99 & 38.5 & 9.58 & 36.6 & 9.38 & 32.7 & 9.13 & 5.51 & $0.000^{* * *}$ \\
\hline Richness & 18.3 & 3.96 & 17.8 & 4.01 & 15.8 & 2.22 & 15.6 & 3.82 & 12.8 & 4.2 & 12.7 & 4.32 & 7.71 & $0.000^{* * *}$ \\
\hline Shannon & 2.73 & 0.26 & 2.7 & 0.22 & 2.57 & 0.23 & 2.52 & 0.23 & 2.47 & 0.19 & 2.34 & 0.42 & 5.96 & $0.000^{* * *}$ \\
\hline Evenness & 1.04 & 0.12 & 0.96 & 0.02 & 0.94 & 0.02 & 0.94 & 0.02 & 0.93 & 0.04 & 0.92 & 0.03 & 11 & $0.000^{* * *}$ \\
\hline BA & 681.5 & 323.6 & 606.2 & 331.8 & 485.3 & 205.1 & 453 & 243 & 349.6 & 5205 & 297.1 & 165.7 & 6.71 & $0.000^{* * *}$ \\
\hline \multicolumn{15}{|l|}{ Saplings } \\
\hline Density & 39.95 & 4.21 & 33.35 & 3.5 & 33.15 & 3.07 & 32.1 & 3.53 & 28 & 3.21 & 24 & 2.9 & 3.97 & 0.49 \\
\hline Richness & 10.5 & 0.51 & 10.5 & 0.51 & 9.75 & 0.72 & 9.7 & 0.57 & 9.9 & 0.72 & 9 & 0.8 & 6.92 & $0.010^{* * *}$ \\
\hline Shannon & 2.26 & 0.05 & 2.27 & 0.05 & 2.22 & 0.08 & 2.24 & 0.08 & 2.16 & 0.08 & 2.13 & 0.1 & 8.56 & $0.004^{* * *}$ \\
\hline Evenness & 1.1 & 0.14 & 0.98 & 0.01 & 0.97 & 0.02 & 0.97 & 0.01 & 0.96 & 0.01 & 0.96 & 0.01 & 0.16 & 0.689 \\
\hline \multicolumn{15}{|l|}{ Seedlings } \\
\hline Density & 44.9 & 9.931 & 32.65 & 9.132 & 38.5 & 9.578 & 36.6 & 9.38 & 43.45 & 5.799 & 41.6 & 7.989 & 44.3 & $0.000^{* * *}$ \\
\hline Richness & 15.8 & 2.215 & 12.7 & 4.318 & 18.3 & 3.962 & 12.8 & 4.2 & 17.75 & 4.011 & 15.55 & 3.818 & 6.25 & $0.014^{* * *}$ \\
\hline Shannon & 2.523 & 0.232 & 2.337 & 0.416 & 2.702 & 0.224 & 2.58 & 0.23 & 2.726 & 0.264 & 2.468 & 0.186 & 1.27 & 0.263 \\
\hline Evenness & 0.934 & 0.043 & 0.921 & 0.034 & 1.037 & 0.121 & 0.94 & 0.02 & 0.962 & 0.017 & 0.944 & 0.025 & 0.87 & 0.352 \\
\hline
\end{tabular}


Table 11 Variations in vegetation attributes across the study communities in the TPFR in Ghana.

\begin{tabular}{|c|c|c|c|c|c|c|c|}
\hline Attribute & BO & NK & AK & SA & HH & AL & P-value \\
\hline \multicolumn{8}{|c|}{ Trees $(\mathrm{DBH} \geq 10 \mathrm{~cm}$, height $=1.3 \mathrm{~m})$} \\
\hline Richness & $17.00 \pm 3.91^{\mathrm{c}}$ & $15.93 \pm 4.46 \mathrm{bc}$ & $14.90 \pm 2.56^{\mathrm{ab}}$ & $14.17 \pm 3.99 \mathrm{ab}$ & $13.70 \pm 4.32 \mathrm{a}$ & $13.27 \pm 4.15 \mathrm{a}$ & $<0.002^{* *}$ \\
\hline \# of indi & $41.50 \pm 10.63 \mathrm{c}$ & $40.73 \pm 6.53 c$ & $38.43 \pm 8.85 b c$ & $38.50 \pm 8.86 \mathrm{bc}$ & $34.97 \pm 9.82^{\mathrm{ab}}$ & $33.43 \pm 8.78 \mathrm{a}$ & $<0.003^{* *}$ \\
\hline Mean SDI & $2.615 \pm 0.24 \mathrm{c}$ & $2.58 \pm 0.32 \mathrm{bc}$ & $2.50 \pm 0.17 \mathrm{abc}$ & $2.41 \pm 0.28 \mathrm{a}$ & $2.43 \pm 0.32 \mathrm{ab}$ & $2.39 \pm 0.37 \mathrm{a}$ & $<0.015^{*}$ \\
\hline Mean SE & $1.00 \pm 0.11 \mathrm{~b}$ & $0.94 \pm 0.03 a$ & $0.94 \pm 0.03 a$ & $0.93 \pm 0.02 \mathrm{a}$ & $0.93 \pm 0.02 \mathrm{a}$ & $0.92 \pm 0.03 a$ & $<0.001^{* *}$ \\
\hline $\mathrm{BA}\left(\mathrm{m}^{2} / \mathrm{ha}\right)$ & $57.10 \pm 19.7 \mathrm{~b}$ & $55.92 \pm 99.2 b$ & $44.58 \pm 14.1 \mathrm{ab}$ & $38.53 \pm 62.7 \mathrm{a}$ & $38.10 \pm 29.1 \mathrm{a}$ & $33.10 \pm 27.1 \mathrm{a}$ & $<0.001^{* *}$ \\
\hline \multicolumn{8}{|c|}{ Saplings $(\mathrm{DBH}<10 \mathrm{~cm}$, height $>1.5 \mathrm{~m}$ ) } \\
\hline Richness & $10.23 \pm 0.62 \mathrm{c}$ & $10.13 \pm 0.73 c$ & $9.86 \pm 0.68 \mathrm{bc}$ & $9.63 \pm 0.55 b$ & $9.56 \pm 0.81$ & $9.10 \pm 0.88 \mathrm{a}$ & $<0.001^{* *}$ \\
\hline \# of indi & $38.13 \pm 4.65$ & $34.10 \pm 3.62$ & $31.83 \pm 3.46$ & $30.70 \pm 3.83$ & $28.53 \pm 3.371$ & $22.87 \pm 3.07$ & $<0.001^{* *}$ \\
\hline Mean SDI & $2.23 \pm 0.05 \mathrm{c}$ & $2.23 \pm 0.07 \mathrm{c}$ & $2.22 \pm 0.08 \mathrm{c}$ & $2.20 \pm 0.08 \mathrm{bc}$ & $2.17 \pm 0.07 \mathrm{~b}$ & $2.10 \pm 0.10 \mathrm{a}$ & $<0.001^{* *}$ \\
\hline Mean SE & $1.05 \pm 0.13 b$ & $0.97 \pm 0.00 \mathrm{a}$ & $0.96 \pm 0.00 \mathrm{a}$ & $0.96 \pm 0.01 \mathrm{a}$ & $0.96 \pm 0.01 \mathrm{a}$ & $0.95 \pm 0.01 \mathrm{a}$ & $<0.001^{* *}$ \\
\hline \multicolumn{8}{|c|}{ Seedlings (DBH $<3 \mathrm{~cm}$, height $<1.5 \mathrm{~m}$ ) } \\
\hline Richness & $6.56 \pm 0.50 \mathrm{c}$ & $6.33 \pm 0.47 \mathrm{bc}$ & $6.23 \pm 0.43 \mathrm{~b}$ & $5.86 \pm 0.43 \mathrm{a}$ & $5.80 \pm 0.61 \mathrm{a}$ & $5.73 \pm 0.63 \mathrm{a}$ & $<0.001^{* *}$ \\
\hline \# of indi & $29.60 \pm 4.46 \mathrm{~d}$ & $27.93 \pm 2.80 \mathrm{~d}$ & $25.57 \pm 3.98 \mathrm{c}$ & $25.27 \pm 3.54 \mathrm{c}$ & $22.93 \pm 4.42 \mathrm{~b}$ & $20.90 \pm 3.96 \mathrm{a}$ & $<0.001^{* *}$ \\
\hline Mean SDI & $1.74 \pm 0.10 \mathrm{~d}$ & $1.69 \pm 0.12 \mathrm{~cd}$ & $1.67 \pm 0.06 \mathrm{bc}$ & $1.64 \pm 0.10 \mathrm{abc}$ & $1.61 \pm 0.13 \mathrm{ab}$ & $1.59 \pm 0.16 \mathrm{a}$ & $<0.001^{* *}$ \\
\hline Mean SE & $0.95 \pm 0.13 b$ & $0.93 \pm 0.044 b$ & $0.92 \pm 0.03 \mathrm{~b}$ & $0.91 \pm 0.02 b$ & $0.90 \pm 0.05 \mathrm{ab}$ & $0.87 \pm 0.16 \mathrm{a}$ & $<0.031^{*}$ \\
\hline
\end{tabular}

Significant differences showed by different letters and the same letters are not statistically significantly different from each other at $\left({ }^{*} \mathrm{P}<0.05,{ }^{* *} \mathrm{P}<0.00\right)$. 
Table 8 Eigen values and percentage of variance explained by CCA along with results of intra-set correlation of trees, saplings and seedlings with soil physicochemical parameters along the TPFR in Ghana.

\begin{tabular}{|c|c|c|c|c|c|c|c|c|c|c|c|c|}
\hline \multirow{2}{*}{ CCA } & \multicolumn{4}{|c|}{ Combined (Trees) } & \multicolumn{4}{|c|}{ Combined (Saplings) } & \multicolumn{4}{|c|}{ Combined (Seedlings) } \\
\hline & Axis 1 & Axis 2 & Axis 3 & Axis 4 & Axis 1 & Axis 2 & Axis 3 & Axis 4 & Axis 1 & Axis 2 & Axis 3 & Axis 4 \\
\hline Eigen Values & 2.12158 & 0.79243 & 0.39919 & 0.16558 & 1.8419 & 0.6298 & 0.2171 & 0.1444 & 1.57713 & 2.53741 & 0.17444 & 0.61197 \\
\hline Species-soil correlations & 0.82441 & 0.66491 & 0.53414 & 0.53414 & 0.8051 & 0.6216 & 0.4224 & 0.3552 & 0.78229 & 0.60794 & 0.46026 & 0.30855 \\
\hline $\begin{array}{l}\text { Cumulative \% variance of } \\
\text { species data }\end{array}$ & 60.9862 & 22.779 & 11.4751 & 4.75968 & 65.0109 & 22.2294 & 7.6629 & 5.0968 & 42.1505 & 24.8426 & 25.5436 & 25.8935 \\
\hline Species-soil relation & 5.93702 & 3.745 & 2.64463 & 1.75514 & 4.0453 & 2.2991 & 1.4277 & 1.2515 & 3.72782 & 2.23407 & 1.45927 & 0.9119 \\
\hline $\begin{array}{l}\text { Sum of all canonical } \\
\text { eigenvalues }\end{array}$ & \multicolumn{4}{|l|}{0.21161} & \multicolumn{4}{|l|}{0.2836} & \multicolumn{4}{|l|}{0.12221} \\
\hline \multicolumn{13}{|c|}{ Inter-Set Correlations for Soil Properties with trees } \\
\hline Variable & Axis 1 & Axis 2 & Axis 3 & Axis 4 & Axis 1 & Axis 2 & Axis 3 & Axis 4 & Axis 1 & Axis 2 & Axis 3 & Axis 4 \\
\hline $\mathrm{pH}$ & -0.305 & 0.3596 & -0.0006 & 0.0571 & $-0.662^{*}$ & -0.551 & -0.272 & 0.003 & $0.74019 *$ & 0.1751 & -0.072 & 0.24988 \\
\hline $\mathrm{OC}$ & $-0.7550^{*}$ & 0.0752 & -0.2828 & -0.0397 & $-0.651^{*}$ & $-0.562^{*}$ & -0.278 & 0.022 & $0.72783^{*}$ & 0.18482 & -0.0588 & 0.22228 \\
\hline TCa & $0.5150^{*}$ & $-0.5522^{*}$ & 0.2246 & 0.0533 & $-0.663^{*}$ & $-0.552^{*}$ & -0.273 & 0.004 & $0.74006^{*}$ & 0.17537 & -0.073 & 0.24832 \\
\hline TMg & 0.486 & 0.007 & -0.1278 & 0.1018 & $0.680^{*}$ & 0.182 & 0.255 & -0.009 & $-0.72029 *$ & -0.1949 & 0.17783 & 0.03513 \\
\hline TK & $0.5590^{*}$ & -0.1879 & 0.2662 & -0.0337 & $0.529^{*}$ & 0.534 & 0.122 & 0.055 & $-0.74677^{*}$ & 0.29335 & 0.10855 & -0.2238 \\
\hline $\mathrm{Na}$ & $0.5590^{*}$ & 0.0349 & 0.0988 & -0.0976 & $0.563^{*}$ & 0.452 & 0.293 & 0.223 & $-0.71872^{*}$ & -0.0334 & 0.07546 & -0.2311 \\
\hline ex. Acidity & $0.5920^{*}$ & -0.0583 & -0.0123 & -0.1524 & 0.414 & $0.564^{*}$ & 0.168 & -0.036 & $-0.54226^{*}$ & 0.07748 & 0.14581 & -0.1895 \\
\hline Base sat & -0.075 & $-0.6605^{*}$ & 0.2865 & 0.3769 & 0.55 & 0.478 & 0.171 & -0.201 & $-0.81357^{*}$ & 0.17323 & 0.03823 & -0.0002 \\
\hline AVI-BRAY 1 (ppmP) & $-0.5980^{*}$ & 0.2851 & -0.3833 & -0.347 & $0.678^{*}$ & 0.336 & 0.234 & -0.018 & $-0.79957^{*}$ & -0.037 & 0.15529 & -0.0365 \\
\hline Sand & -0.199 & 0.1957 & -0.1952 & 0.347 & 0.373 & -0.353 & 0.246 & 0.317 & -0.0885 & -0.4891 & 0.35186 & -0.0602 \\
\hline Clay & 0.039 & -0.1036 & 0.2801 & -0.2567 & $-0.674^{*}$ & -0.288 & 0.053 & 0.013 & 0.49989 & 0.32076 & -0.4359 & -0.1573 \\
\hline Silt & 0.248 & -0.2546 & -0.039 & -0.2573 & -0.247 & 0.108 & -0.417 & 0.228 & 0.3503 & 0.43019 & 0.02567 & -0.3005 \\
\hline
\end{tabular}


Table 9 Eigen values and percentage of variance explained by CCA along with results of intra-set correlation of trees with soil physicochemical parameters in the six studied communities.

\begin{tabular}{|c|c|c|c|c|c|c|c|c|c|c|c|c|}
\hline \multirow{2}{*}{ CCA } & \multicolumn{2}{|l|}{$\mathrm{BO}$} & \multicolumn{2}{|l|}{ NK } & \multicolumn{2}{|l|}{$\mathrm{AK}$} & \multicolumn{2}{|l|}{ SA } & \multicolumn{2}{|l|}{$\mathrm{HH}$} & \multicolumn{2}{|l|}{ AL } \\
\hline & Axis 1 & Axis 2 & Axis 1 & Axis 2 & Axis 1 & Axis 2 & Axis 1 & Axis 2 & Axis 1 & Axis 2 & Axis 1 & Axis 2 \\
\hline Eigen Values & 154.705 & 45.103 & 298.876 & 5.646 & 98.994 & 2.503 & 88.858 & 10.404 & 88.277 & 11.566 & 15.982 & 0.8297 \\
\hline tree-soil correlations & 0.997 & 0.989 & 0.998 & 0.921 & 0.994 & 0.845 & 0.994 & 0.912 & 0.994 & 0.9593 & 0.97 & 0.673 \\
\hline Cumulative $\%$ variance of species data & 73.969 & 26.031 & 98.145 & 1.854 & 97.533 & 2.503 & 88.962 & 11.038 & 82.814 & 17.185 & 98.777 & 1.222 \\
\hline tree-soil relation & 32.2 & 22.55 & 16.78 & 2.523 & 6.813 & 1.251 & 11.58 & 5.202 & 12.497 & 5.7831 & 1.759 & 0.414 \\
\hline Sum of all canonical eigenvalues & \multicolumn{2}{|l|}{0.157} & \multicolumn{2}{|l|}{4.0206} & \multicolumn{2}{|l|}{0.2343} & \multicolumn{2}{|l|}{0.2574} & \multicolumn{2}{|l|}{0.00935} & \multicolumn{2}{|c|}{0.65289} \\
\hline \multicolumn{13}{|c|}{ Inter-Set Correlations for Soil Properties with trees } \\
\hline Variable & Axis 1 & Axis 2 & Axis 1 & Axis 2 & Axis 1 & Axis 2 & Axis 1 & Axis 2 & Axis 1 & Axis 2 & Axis 1 & Axis 2 \\
\hline $\mathrm{pH}$ & 0.722 & -0.462 & 0.86 & -0.439 & 0.664 & -0.35 & -0.8 & 0.4311 & 0.935 & -0.204 & -0.193 & 0.11 \\
\hline $\mathrm{OC}$ & 0.97 & 0.094 & 0.935 & -0.19 & 0.455 & -0.38 & -0.85 & 0.3691 & 0.947 & -0.198 & -0.285 & 0.123 \\
\hline $\mathrm{TN}$ & 0.97 & 0.094 & 0.935 & -0.19 & 0.455 & -0.38 & -0.85 & 0.3691 & 0.947 & -0.198 & -0.285 & 0.123 \\
\hline $\mathrm{OM}$ & 0.97 & 0.094 & 0.935 & -0.19 & 0.455 & -0.38 & -0.85 & 0.3691 & 0.947 & -0.198 & -0.285 & 0.123 \\
\hline $\mathrm{TCa}$ & -0.849 & 0.367 & -0.915 & 0.21 & -0.84 & 0.212 & 0.606 & -0.639 & -0.92 & 0.048 & 0.423 & -0.033 \\
\hline $\mathrm{TMg}$ & -0.807 & 0.418 & -0.981 & 0.165 & -0.7 & 0.41 & 0.785 & -0.487 & -0.98 & 0.01 & 0.367 & -0.102 \\
\hline TK & -0.835 & 0.349 & -0.95 & 0.102 & -0.77 & 0.319 & 0.774 & -0.499 & -0.91 & 0.028 & 0.359 & -0.028 \\
\hline $\mathrm{Na}$ & -0.872 & 0.346 & -0.947 & 0.239 & -0.84 & 0.248 & 0.817 & -0.445 & -0.93 & 0.123 & 0.313 & -0.112 \\
\hline T.E.B & -0.843 & 0.383 & -0.943 & 0.203 & -0.83 & 0.241 & 0.652 & -0.621 & -0.95 & 0.037 & 0.398 & -0.068 \\
\hline ex. Acidity & -0.985 & 0.085 & -0.803 & 0.335 & -0.67 & 0.337 & 0.8 & -0.413 & -0.92 & 0.05 & 0.368 & -0.124 \\
\hline ECEC & -0.873 & 0.351 & -0.951 & 0.22 & -0.81 & 0.255 & 0.669 & -0.61 & -0.95 & 0.039 & 0.395 & -0.078 \\
\hline Base sat & 0.311 & 0.697 & -0.416 & -0.177 & -0.8 & -0.19 & 0.596 & -0.696 & 0.749 & -0.11 & -0.099 & 0.178 \\
\hline AVI-P 1 (ppmP) & 0.888 & -0.09 & 0.747 & -0.512 & 0.844 & -0.27 & -0.85 & 0.3886 & 0.44 & -0.136 & -0.301 & -0.174 \\
\hline Sand & 0.103 & 0.331 & 0.359 & 0.563 & 0.219 & -0.55 & -0.045 & 0.2619 & 0.171 & -0.25 & 0.477 & 0.618 \\
\hline Clay & 0.149 & -0.169 & -0.505 & -0.429 & -0.126 & 0.424 & -0.052 & -0.058 & 0.14 & 0.039 & 0.177 & -0.415 \\
\hline Silt & -0.238 & -0.339 & -0.007 & -0.524 & -0.23 & 0.407 & 0.072 & -0.313 & -0.278 & 0.408 & -0.595 & -0.275 \\
\hline
\end{tabular}


Table 10 Canonical Inter-set Correlation for the first two axes of CCA for saplings with soil properties in the six communities in TPFR.

\begin{tabular}{|c|c|c|c|c|c|c|c|c|c|c|c|c|}
\hline \multirow{2}{*}{ CCA } & \multicolumn{2}{|l|}{ BO } & \multicolumn{2}{|l|}{ NK } & \multicolumn{2}{|l|}{$\mathrm{AK}$} & \multicolumn{2}{|l|}{ SA } & \multicolumn{2}{|l|}{$\mathrm{HH}$} & \multicolumn{2}{|l|}{ AL } \\
\hline & Axis 1 & Axis 2 & Axis 1 & Axis 2 & Axis 1 & Axis 2 & Axis 1 & Axis 2 & Axis 1 & Axis 2 & Axis 1 & Axis 2 \\
\hline Eigen Values & 1799.53 & 1.7667 & 231.937 & 0.888 & 10.731 & 1.6785 & 106.258 & 1.443 & 286.45 & 3.2349 & 20.7504 & 4.9435 \\
\hline Saplings-soil correlations & 0.9997 & 0.7991 & 0.9979 & 0.6858 & 0.9564 & 0.7916 & 0.9953 & 0.7686 & 0.9983 & 0.874 & 0.9767 & 0.912 \\
\hline Cumulative (\%) variance of saplings data & 64.9076 & 33.197 & 64.0561 & 32.937 & 8.6186 & 11.768 & 41.8523 & 44.75 & 61.912 & 4.916 & 35.7175 & 8.866 \\
\hline Saplings-soil relation & 13.9159 & 0.5048 & 3.9942 & 0.2537 & 0.9211 & 0.4796 & 3.0375 & 0.4123 & 9.6829 & 1.2442 & 2.074 & 1.4124 \\
\hline Sum of all canonical eigenvalues & \multicolumn{2}{|l|}{86.7164} & & & \multicolumn{2}{|l|}{3.3562} & & & \multicolumn{2}{|c|}{2.1543} & & \\
\hline \multicolumn{13}{|c|}{ Inter-Set Correlations for soil properties with saplings } \\
\hline Variable & Axis 1 & Axis 2 & Axis 1 & Axis 2 & Axis 1 & Axis 2 & Axis 1 & Axis 2 & Axis 1 & Axis 2 & Axis 1 & Axis 2 \\
\hline $\mathrm{pH}$ & 0.9624 & 0.03 & 0.9624 & 0.03 & -0.323 & -0.08 & 0.6681 & 0.274 & 0.949 & -0.11 & 0.7057 & -0.063 \\
\hline $\mathrm{OC}$ & 0.9611 & 0.038 & 0.9611 & 0.038 & -0.294 & -0.11 & 0.6793 & 0.261 & 0.941 & -0.13 & 0.6708 & -0.042 \\
\hline $\mathrm{TN}$ & 0.9628 & 0.027 & 0.9628 & 0.027 & -0.32 & -0.08 & 0.6686 & 0.275 & 0.949 & -0.11 & 0.7074 & -0.064 \\
\hline $\mathrm{OM}$ & -0.868 & 0.057 & -0.868 & 0.057 & 0.253 & 0.315 & -0.837 & -0.01 & -0.903 & 0.181 & -0.819 & -0.078 \\
\hline $\mathrm{TCa}$ & -0.948 & -0.07 & -0.948 & -0.07 & 0.398 & 0.177 & -0.644 & -0.22 & -0.985 & 0.06 & -0.803 & -0.19 \\
\hline $\mathrm{TMg}$ & -0.965 & -0.04 & -0.965 & -0.04 & 0.364 & 0.212 & -0.779 & -0.14 & -0.904 & 0.032 & -0.835 & -0.163 \\
\hline TK & -0.925 & 0.023 & -0.925 & 0.023 & 0.332 & 0.367 & -0.68 & -0.22 & -0.909 & 0.146 & -0.755 & -0.207 \\
\hline $\mathrm{Na}$ & -0.771 & -0.13 & -0.771 & -0.13 & 0.331 & 0.17 & -0.641 & -0.16 & - & - & -0.75 & -0.146 \\
\hline T.E.B & -0.908 & 0.02 & -0.908 & 0.02 & 0.285 & 0.284 & -0.811 & -0.06 & -0.941 & 0.108 & -0.815 & -0.14 \\
\hline ex. Acidity & -0.417 & 0.191 & -0.417 & 0.191 & 0.041 & 0.272 & -0.869 & -0.06 & 0.777 & 0.281 & 0.0478 & 0.087 \\
\hline ECEC & 0.8422 & -0.04 & 0.8422 & -0.04 & -0.284 & -0.36 & 0.6713 & 0.305 & 0.313 & -0.55 & -0.286 & 0.409 \\
\hline Base sat & 0.3463 & 0.582 & 0.3463 & 0.582 & -0.357 & -0.11 & -0.023 & 0.316 & 0.127 & -0.11 & -0.086 & -0.218 \\
\hline AVI-BRAY 1 (ppmP) & -0.489 & -0.46 & -0.489 & -0.46 & 0.223 & 0.132 & 0.1412 & -0.11 & 0.204 & 0.163 & -0.169 & -0.073 \\
\hline Sand & 0.0109 & -0.55 & 0.0109 & -0.55 & 0.33 & 0.043 & -0.066 & -0.36 & -0.26 & 0.099 & 0.1714 & 0.284 \\
\hline Clay & 0.8782 & -0.07 & 0.8782 & -0.07 & -0.31 & -0.28 & 0.707 & 0.182 & 0.933 & -0.08 & 0.4576 & -0.043 \\
\hline Silt & 0.9624 & 0.03 & 0.9624 & 0.03 & -0.323 & -0.08 & 0.6681 & 0.274 & 0.949 & -0.11 & 0.7057 & -0.063 \\
\hline
\end{tabular}


Table 11 Results of Canonical Correlation Analysis (CCA) with seedlings with soil characteristics from the six communities in the TPFR.

\begin{tabular}{|c|c|c|c|c|c|c|c|c|c|c|c|c|}
\hline \multirow{2}{*}{ CCA } & \multicolumn{2}{|l|}{ BO } & \multicolumn{2}{|l|}{ NK } & \multicolumn{2}{|l|}{$\mathrm{AK}$} & \multicolumn{2}{|l|}{ SA } & \multicolumn{2}{|l|}{$\mathrm{HH}$} & \multicolumn{2}{|l|}{$\mathrm{AL}$} \\
\hline & Axis 1 & Axis 2 & Axis 1 & Axis 2 & Axis 1 & Axis 2 & Axis 1 & Axis 2 & Axis 1 & Axis 2 & Axis 1 & Axis 2 \\
\hline Eigen Values & 1525.562 & 62.446 & 185.853 & 0.434 & 239.941 & 17.203 & 19.402 & 8.122 & 65.709 & 2.011 & 62.442 & 1.553 \\
\hline $\begin{array}{l}\text { Seedlings-soil } \\
\text { correlations }\end{array}$ & 1 & 1 & 0.997 & 0.55 & 0.998 & 0.972 & 0.975 & 0.944 & 0.992 & 0.817 & 0.992 & 0.78 \\
\hline $\begin{array}{l}\text { Cumulative \% variance } \\
\text { of species data }\end{array}$ & 88.073 & 2.726 & 75.347 & 8.678 & 65.601 & 8.698 & 40.124 & 27.111 & 45.6 & 9.217 & 49.363 & 4.928 \\
\hline Seedlings-soil relation & 62.0429 & 17.8417 & 3.07349 & 0.12392 & 13.045 & 4.9151 & 2.5284 & 2.3206 & 3.7633 & 0.77328 & 2.34524 & 0.44336 \\
\hline $\begin{array}{l}\text { Sum of all canonical } \\
\text { eigenvalues }\end{array}$ & \multicolumn{2}{|l|}{8.1867} & \multicolumn{2}{|l|}{0.2855} & \multicolumn{2}{|l|}{2.35253} & \multicolumn{2}{|l|}{0.60633} & \multicolumn{2}{|l|}{0.05994} & \multicolumn{2}{|l|}{0.44696} \\
\hline \multicolumn{13}{|c|}{ Inter-Set Correlations for soil properties with seedlings } \\
\hline Variable & Axis 1 & Axis 2 & Axis 1 & Axis 2 & Axis 1 & Axis 2 & Axis 1 & Axis 2 & Axis 1 & Axis 2 & Axis 1 & Axis 2 \\
\hline $\mathrm{pH}$ & 0.95405 & 0.11486 & -0.1719 & -0.31176 & 0.9465 & 0.12235 & -0.434 & -0.324 & 0.7601 & -0.1666 & 0.41034 & 0.45907 \\
\hline OC & 0.71738 & 0.37743 & -0.2735 & -0.28371 & 0.8546 & -0.0551 & -0.465 & -0.3976 & 0.748 & -0.1309 & 0.699 & 0.33371 \\
\hline $\mathrm{TN}$ & 0.7344 & 0.34468 & -0.2771 & -0.26977 & 0.8428 & -0.0172 & -0.45 & -0.3967 & 0.7332 & -0.0985 & 0.6686 & 0.32184 \\
\hline $\mathrm{OM}$ & 0.71946 & 0.3751 & -0.2755 & -0.28448 & 0.8554 & -0.0547 & -0.466 & -0.3955 & 0.7474 & -0.1326 & 0.7005 & 0.33538 \\
\hline $\mathrm{TCa}$ & -0.9553 & -0.1685 & 0.21337 & 0.35185 & -0.943 & -0.2992 & 0.4675 & 0.051 & -0.857 & 0.03802 & -0.784 & -0.4164 \\
\hline $\mathrm{TMg}$ & -0.9752 & -0.1466 & 0.16402 & 0.36758 & -0.972 & -0.0424 & 0.3946 & 0.2827 & -0.887 & 0.07615 & -0.777 & -0.3107 \\
\hline TK & -0.942 & -0.2272 & 0.25953 & 0.33258 & -0.979 & -0.0848 & 0.4437 & 0.2941 & -0.856 & -0.0073 & -0.777 & -0.4069 \\
\hline $\mathrm{Na}$ & -0.9359 & -0.1824 & 0.20073 & 0.36542 & -0.923 & -0.2687 & 0.5 & 0.3588 & -0.776 & 0.2409 & -0.706 & -0.3641 \\
\hline ex. Acidity & -0.8377 & -0.2783 & -0.1109 & 0.31457 & -0.945 & -0.109 & 0.4961 & 0.333 & - & - & -0.739 & -0.3046 \\
\hline ECEC & -0.9642 & -0.1813 & 0.18509 & 0.36431 & -0.959 & -0.2457 & 0.4714 & 0.1162 & -0.876 & 0.05364 & -0.786 & -0.3613 \\
\hline Base sat & -0.2426 & 0.19164 & 0.49964 & 0.11526 & -0.3901 & -0.3694 & 0.4399 & 0.0104 & 0.6554 & -0.2421 & 0.07333 & 0.16472 \\
\hline AVI-P 1 (ppmP) & 0.91923 & 0.09891 & -0.1088 & -0.27792 & 0.9461 & 0.26354 & -0.467 & -0.3854 & 0.3072 & -0.5347 & -0.2697 & -0.0233 \\
\hline Sand & -0.0127 & -0.0396 & -0.1651 & 0.37015 & 0.35907 & -0.0547 & 0.506 & 0.0916 & 0.0597 & -0.3322 & -0.0915 & -0.4036 \\
\hline Clay & 0.24008 & 0.0183 & 0.16807 & -0.12043 & -0.1945 & 0.09132 & -0.364 & -0.0194 & 0.2569 & 0.2965 & -0.19 & 0.16437 \\
\hline Silt & -0.1225 & 0.02162 & 0.07491 & -0.58645 & -0.3749 & -0.1001 & -0.509 & -0.1435 & -0.1767 & 0.27418 & 0.19374 & 0.26828 \\
\hline
\end{tabular}




\section{Discussion}

The study sought to analyse the influence of soil physicochemical parameters on vegetation (trees, saplings, seedlings) composition and structure along the TPFR and across the fringed communities. The composition and structure of the various groups (trees, saplings and seedlings) were influenced by 15 soil physicochemical parameters along the plateau and across the study communities based on the first two axes of the CCA.

\subsection{Variation among the soil physicochemical properties in the Togo Plateau Forest Reserve}

The coefficients of variation (CV) were used to estimate the variability in soil properties. Several studies have documented CV values for soil physico-chemical properties to be low (c.v.<15\%), moderate (c.v. $=15 \%-34 \%$ ) and high (c.v. $>35 \%)[6,8,10,13]$. This study in the TPFR in Ghana indicated that the CV values for most of the soil properties including OC, TN, OM, TCa, TMg, Na, T.E.B, ex. ACIDITY, ECEC, and AVI-P 1were in the range of between $37.5 \%$ to $61.7 \%$ and the soils area tended to be somewhat weak acidic to neutral, with a pH ranging between 4.17 and 7.06 [Table 1] which generally is in the range of results obtained from other similar studies $[610,13]$. Therefore, soils in the study area were highly variable. This is evidenced in the plateau being floristically rich. The accounting factor for this trend could be that the vegetation was supplying a high amount of litter to the soil [10]. In addition, the most important species in the study area (see Table 9) have a strong nitrogen fixation function and thus, the available $\mathrm{K}$ and total $\mathrm{N}$ contents increased $[6,10,13]$. Studies have shown that high soil organic matter, P-retention capacity, ex. ACIDITY, ECEC, and AVI-P 1presents surface accumulation and has a significant influence on vegetation growth and development, and different vegetation types may also increase the soil organic matter to different degrees because a high amount of litter was introduced $[6,10,13]$. And the decomposition by microorganisms resulted in a greater amount of humus, and increases in the soil organic matter. The pattern of variation observed along the landscape may be due to different quantum of deposition of organic matter $[6,8,10]$.

\subsection{Soil, vegetation composition and structure across the six communities in the TPFR}

The results demonstrated variations in concentrations of soils physicochemical parameters across the six study communities. These results which is considered as a major characteristic of several plateau forests $[3,2,7,12]$ support the hypothesis that soil physicochemical properties are the main factor determining the variations in species composition and structure in plateau ecosystems [2]. Accounting factor might be the influence of environmental heterogeneity on the landscape which results in the creation of edaphic gradients [7]. The trees structural differences exhibited across the six communities forest formations on the landscape is in line with several documented studies that composition and structure of vegetation can vary across landscapes that are at least a hundred meters apart topographic range $[1,14]$. In this study, vegetation attributes (density, richness, Shannon, evenness and BA) all follow a similar patterns of distribution a across the communities. All were highest for BO, NK AK and lowest for SA, HH and AL. This similar trend of distribution was also seen among the saplings and seedlings. Another probable explanation may be that BO, NK AK lie in lowland areas on the plateau and these habitats have better and higher variations in composition of soil physicochemical parameters that affected the structure of plant communities and therefore showed high values for density and basal area [9]. On the other hand, SA, HH and AL lie on the highland area on the plateau and these habitats have relatively poor soil physicochemical properties that affected the structure of their plant communities and therefore showed low values for density and basal area [2]. Therefore, the structural complexity of the vegetation of the TPFR in Ghana strongly correlates with soil physicochemical parameters and agrees with the reports from similar studies $[3,2$, 7].

In the case of richness, Shannon, evenness which measures diversity, BO, NK and AK again showed a higher significant difference among habitats than SA, HH and AL (Table 10). This may be due to the communities exhibiting a distinct soil types that result in habitat differentiation [2]. Soil characterization have been well documented as the main factor that influences plant diversity in landscapes $[7,14,5,8]$. Trees for instance have been documented to have a strong positive correlation with diversity under favourable environmental conditions [8].

\subsection{Effect of soil physicochemical on vegetation distribution}

The results obtained from the CCA analysis suggest that soil plays a more important role in the determination of composition and structure of vegetations in plateau forest habitats. Canonical Correlation Analysis (CCA) results showed that pH, OC, TN, OM, TCa, TMg, TK, Na, T.E.B, ex. Acidity, ECEC, Base sat, AVI - P (ppmP), Sand and Silt were the drivers of species (trees, saplings and seedlings) composition and structure (including density, richness, Shannon, evenness and BA) along the plateau and across the study communities. However, vegetation attributes were seen to be highest and more correlated with soil physicochemical parameters for BO, NK and AK occupying lowland and lowest in the SA, HH and AL which occupy highland areas of the plateau. 
A similar relationship has been reported for a number of tropical forest sites $[2,8,14]$. Although five communities have similar soil parameters controlling the vegetation with one distinct community, their concentrations (which is controlled by nutrient and water availability) vary from one community to the other due to different gradients created and consequently results in vegetation distribution variation across landscapes sites $[8,14]$.

This result also agrees with similar studies that for a number of tropical forest sites vegetation and soil characteristics distribution varies $[3,2,7]$. In plateau landscape-scale, variation in functional community composition and distribution results from local-scale specialization of a given species in response to its filtering of the locally available species pool by physical and chemical soil properties [3]. Studies on differences in plant functional community composition and distribution across edaphic gradients in plateau ecosystems have reported a general trend that sites with lower resource availability and nutrient retention contained less diverse and distributed plant communities than those with ample soil water and nutrient supply [2]. From the study, BO, NK and AK have a more neutral pH levels than SA, HH and AL. This report agrees with other studies that across topo-edaphic gradients, plateau forests are generally characterized by a more neutral $\mathrm{pH}$ levels in lower gradients which is beneficial to the decomposition of soil organic matter by microorganisms and affects the release of phosphorus than higher gradient and this promotes growth and wide distribution of species in lowland sites $[1,14]$. This result which account for local habitat heterogeneity also confirms that every species has different growth and distribution strategy for local edaphic gradients and therefore plant community composition is shaped by soil resource availability $[1,14]$.

\section{Conclusion}

Soil - Species correlation studies must be the first step in understanding the diversity and ecology of plateau ecosystems, because knowledge of the diversity and ecological needs of the species provide clues for the particularly species growing in special locations along and across plateau fringed communities. In the TPFR in Ghana, the canonical correlation analysis (CCA) results showed that pH, OC, TN, OM, TCa, TMg, TK, Na, T.E.B, ex. Acidity, ECEC, Base sat, AVI - P (ppmP), Sand and Silt were the drivers of tree composition and structure (including density, richness, Shannon, evenness and BA), saplings (richness and Shannon) and seedlings (density and richness) along the plateau and across the study communities. However, vegetation attributes were seen to be highest and more correlated with soil physicochemical parameters for BO, NK, AK occupying lowland and lowest in the SA, HH and AL which occupy highland areas of the plateau. The soil of the study area tended to be a somewhat weak acidic to neutral, with a pH ranging between 4.17 and 7.06. The $\mathrm{CV}$ values are well within the standard values with Base sat showing lowest values (c.v.<15\%), with moderate values of (c.v.=34\%-15\%) for TK and highest values (c.v.>35\%) for TCa, TMg, Na, T.E.B, ex. ACIDITY, ECEC, AVI-P1 on the landscape. The study provides a better understanding of the current status so as to assist in the management of this plateau in Ghana.

\section{Compliance with ethical standards}

\section{Acknowledgments}

The authors acknowledge the Forest Services Division, Jasikan District in the Oti Region of Ghana who allocated forest guards to us who took us round the whole of the plateau during the data collection.

\section{Disclosure of conflict of interest}

The authors declare that there is no conflict of interest.

\section{References}

[1] Bhandari J, Y Zhang. Effect of altitude and soil properties on biomass and plant richness in the grasslands of Tibet, China \& Manang District, Nepal. Ecosphere. 2019; 10(11): e02915.

[2] Carrick PJ, Forsythe KJ. The species composition-ecosystem function relationship: A global meta-analysis using data from intact and recovering ecosystems. PLoS ONE. 2020; 15(7): e0236550.

[3] Erktan AM, McCormack L, Roumet C. Frontiers in root ecology: recent advances and future challenges. Springer International Publishing AG. 2018.

[4] Ghana Statistical Service (GSS). Population and Housing Census (PHC). 2010. 
[5] Luna-Kamyshev NM, Lopez-Martınez JO, Vargas-Larreta B, Islebe1 GA, Villalobos-Guerrero TF, Vazquez de la Rosa A, Oscar F, Mendoza RA, Trevino-Garza E. Floristic Composition, Diversity, and Biomass of a Protected Tropical Evergreen Forest Belize. Tropical Conservation Science. 2020; 13: 1-13.

[6] Metwally MS, Shaddad SM, Liu M, Yao RJ, Abdo AI, Li P, Jiao J, Chen X. Soil Properties Spatial Variability and Delineation of Site-Specific Management Zones Based on Soil Fertility Using Fuzzy Clustering in a Hilly Field in Jianyang, Sichuan, China. Sustainability. 2019; 11: 7084.

[7] Midolo G, Alkemade R, Schipper AM, Benítez-López A, Perring MP, Vries WD. Impacts of nitrogen addition on plant species richness and abundance: A global meta-analysis. Global Ecology and Biogeography: John Wiley \& Sons Ltd. 2018.

[8] Neri AV, Rodrigues AC, Villa PM, Ali A, Ferreira-Junior W. Fine-scale habitat differentiation shapes the composition, structure and aboveground biomass but not species richness of a tropical Atlantic forest. J. For. Res. 2019.

[9] Priscyla Maria Silva Rodrigues, Carlos Ernesto Gonçalves Reynaud Schaefer, Jhonathan de Oliveira Silva, Walnir Gomes Ferreira Júnior, Rubens Manoel dos Santos \& Andreza Viana Neri. The influence of soil on vegetation structure and plant diversity in different tropical savannic and forest habitats. Journal of Plant Ecology. 2018; 11(2): 226-236.

[10] Soong JL, Janssens IA, Grau O, Margalef O, Stahl C, Langenhove LV, Urbina I, Chave J, Dourdain A, Ferry B, Freycon V, Herault B, Sardans J, Peñuelas J, Verbruggen E. Soil properties explain tree growth and mortality, but not biomass, across phosphorus-depleted tropical forests. Scientific Reports. 2020; 10: 2302.

[11] Sumasgutner P, Terraube J, Aurélie Coulon A, Villers A, Chakarov N, Kruckenhauser L, Korpimäki E. Landscape homogenization due to agricultural intensification disrupts the relationship between reproductive success and main prey abundance in an avian predator. Frontiers in Zoology. 2019.

[12] Sun C, Chai Z, Liu G, Xue S. Changes in Species Diversity Patterns and Spatial Heterogeneity during the Secondary Succession of Grassland Vegetation on the Loess Plateau, China. Front. Plant Sci. 2019; 8: 1465.

[13] Yao X, Yu K, Deng Y, Liu J \& Lai Z. Spatial variability of soil organic carbon and total nitrogen in the hilly red soil region of Southern China. J. For. Res. 2019.

[14] Zhang B, Zhang H, Jing Q, Wu Y, Ma S. Differences in species diversity, biomass, and soil properties of five types of alpine grasslands in the Northern Tibetan Plateau. PLoS. ONE. 2020; 15(2): e0228277. 